\begin{tabular}{lllll}
\hline$\backslash$ jciprod01 \productn $\backslash L \backslash L C A \backslash 18-2 \backslash$ lca204.txt & unknown & Seq: 1 & 6-AUG-12 & 11:45
\end{tabular}

\title{
AN INTERNATIONAL TREATY FOR ANIMAL WELFARE
}

\author{
By \\ David Favre*
}

Currently there is no international agreement that ensures the welfare and protection of animals. Nor is there any international standard that regulates and defines the acceptable treatment of animals. This lack of international consensus leads to the current disparate treatment of animals around the world, echoing the need for an international framework addressing the issue. This Article discusses a proposed umbrella treaty, the International Convention for the Protection of Animals (ICPA). This umbrella treaty would enable animal welfare issues to gain international recognition and protection by setting the general guidelines and polices regarding the treatment and use of animals. This Article argues that this is the best way to successfully pursue international protection by reconciling the conflicting goals of making a treaty enticing to as many countries as possible without eliminating enforcement mechanisms. This Article also suggests four companion protocols that would further delineate specific animal welfare standards and requirements. With the present economic climate, it may be difficult to convince countries to pass such a treaty. However, the ICPA could make it possible to begin the process of enacting groundbreaking international animal protection.

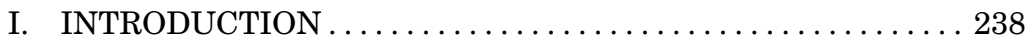

II. THE NATURE AND ROLE OF TREATIES . . . . . . . . . 240

III. THE NEED FOR AN ANIMAL WELFARE TREATY . . . . . . . 243

A. The Lack of Existing International Law ............ 245

B. The International Movement of Animals ............ 246

C. Fostering Discussion and Consensus ............. 247

D. Reducing Negative Economic Incentives ........... 248

E. Default Standards of OIE Are Not Sufficient .......... 251

IV. HOW TO BUILD AN ANIMAL WELFARE TREATY .... . . . 252

* (c) David Favre 2012. David Favre is a Professor of Law and The Nancy Heathcote Professor of Property and Animal Law at Michigan State University College of Law. He has written extensively on the subjects of animal law, animal cruelty, and wildlife law. Professor Favre's scholarship frequently emphasizes international control of the animal trade. Currently he serves on the ABA Committee on Animal Law. Professor Favre has also published seven books on animal law including: Animals: Welfare, Interests and Rights, Animal Law and Dog Behavior, Animal Law: Welfare, Interest, and Rights, and International Trade in Endangered Species. The author would like to thank Associate Editors Christopher Graves and Kimberly White, who oversaw review of this Article, along with the Form and Style Editor Claire Poulin and the rest of the Animal Law Review staff. 


\section{INTRODUCTION}

Many critical environmental issues today cannot be resolved without international agreements. As part of the struggle to further environmental and human rights issues, proponents of these causes utilize treaties, conventions, and declarations to find standards and procedures to address these issues on a global basis. Until now, the issue of the care and well being of the nonhuman inhabitants of this planet has had no equivalent international focal point. Because of human need, greed, ignorance, and vanity, untold numbers of animals throughout the world suffer and die on a daily basis. While thousands of humans work daily to reduce this toll, a more visible, efficient, and universal standard is needed. The immediate elimination of animal pain and suffering is not likely. Therefore, a mechanism under which progress for animal welfare can be realized as fast as moral persuasion, technology, economic development, and political support will accommodate it. The adoption of the International Convention for the Protection of Animals (ICPA) can be one important legal and political tool in the process of progress for animals.

Some countries have adopted serious laws for dealing with animal welfare issues. ${ }^{1}$ Others have welfare laws but inadequate enforcement resources or political will to carry out their laws. ${ }^{2}$ Some countries have neither enacted meaningful laws nor expressed a legitimate interest in

\footnotetext{
1 See e.g. Animal Welfare Act 1999 (N.Z.) (available at http://www.legislation.govt. nz/act/public/1999/0142/latest/DLM49664.html (updated July 7, 2010) (accessed Apr. 8, 2012)) (a comprehensive animal welfare statute); James Andrews, Food Safety News, European Union Bans Battery Cages for Egg-Laying Hens, http://www.foodsafetynews. com/2012/01/european-union-bans-battery-cages-for-egg-laying-hens/ (Jan. 19, 2012) (accessed Apr. 8, 2012) (showing a new example of strong legislation for all European Union (EU) countries regarding battery cages); Animal Leg. \& Historical Ctr., World Materials, http://www.animallaw.info/nonus/index.htm (accessed Apr. 8, 2012) (listing various animal laws from around the world, divided by country); Associated Press, Bolivia Bans All Circus Animals, The Guardian (July 31, 2009) (available at http://www. guardian.co.uk/world/2009/jul/31/bolivia-bans-circus-animals (accessed Apr. 8, 2012)) (reporting on the first country to have a strict ban on all circus animals).

2 See e.g. Michael Bowman et al., International Wildlife Law 5, 113 (2d ed., Cambridge U. Press 2010) (describing the difficulty of enforcement and implementation of wildlife protection laws); Thomas G. Kelch, Globalization and Animal Law: Comparative Law, International Law, and International Trade vol. 32, 232 (Ross Buckley ed., Global Trade L. Series, Wolters Kluwer 2011) (stating the difficulty of enforcement for countries).
} 
dealing with animal issues. ${ }^{3}$ At present, there is no international animal welfare standard by which to judge the legislative efforts within one country. Also, at the moment, every battle has to be fought over and over again in each country as those trying to help animals seek to justify new laws and restrictions. With the ICPA, there will be an accepted standard, which is immediately accessible to all the nation states, organizations, and individuals of the world. The adoption of the ICPA will give more credibility and weight to all of the local efforts on behalf of animals. With the ICPA, local groups can stop using their finite resources to advocate for what the standards ought to be, and instead could use them to further the implementation of the standards that have been accepted within the Convention.

The term "animal rights" is part of the legal conversation in only a few countries. "Animal welfare," and its supporting concepts, is the best available and most acceptable term in most countries. ${ }^{5}$ Certainly, among diplomats, the term "animal rights" will only cause confusion and suspicion. Species protection is the only language culturally acceptable in many countries. ${ }^{6}$ At this point in time, seeking to draft a treaty for the legal rights of animals would not be useful. First, most governments would not give it serious consideration. Second, it would be disrespectful to seek legal rights for animals when so many humans around the world still struggle for their rights.

This Article will first develop a quick background on the nature of treaties in Part II and reasons for seeking an animal welfare treaty in Part III. It next focuses on how to structure a specific umbrella treaty in Part IV. Finally, Part V considers the prospects for the adoption of the treaty. An appendix to this Article contains a full draft treaty, but the Article only discusses a few selected examples from that draft.

3 See generally John Sorenson, Canada: No Country for Animals, http://www.the marknews.com/articles/1957-canada-no-country-for-animals (Aug. 3, 2010) (accessed Apr. 8, 2012) (describing a documentary on the poor state of Canada's animal welfare laws); Treehugger, Four Worst Places to Be an Endangered Species, http://www.treehugger.com/natural-sciences/four-worst-places-to-be-an-endangered-species.html (Dec. 3, 2008) (accessed Apr. 8, 2012) (showing examples of countries with poor endangered species protection).

4 See e.g. Kelch, supra n. 2, at 271, 304 (discussing the difficulty of usage of the term "animal rights" and an example of a country whose legislation grants rights in limited circumstances).

5 See Robert Garner, Animal Welfare: A Political Defense, 1 J. Animal L. \& Ethics $161,163,169-70$ (2006) (discussing the political value of animal welfare, compared to animal rights).

6 See generally The Mohamed bin Zayed Species Conserv. Fund, Species Conservation: An Endangered Environmental Priority 1-2 (Mohamed bin Zayed 2009) (available at http://www.mbzspeciesconservation.org/media/mbz-species-conservation-fund-14.pdf (accessed Apr. 8, 2012)) (describing the trend of favoring species conservation for their inherent use and value to humans and then later for the aesthetic value). 
\begin{tabular}{lllll}
\hline$\backslash$ jciprod01\productn $\backslash L \backslash L C A \backslash 18-2 \backslash$ lca204.txt & unknown & Seq: 4 & 6-AUG-12 & $11: 45$ \\
\hline
\end{tabular}

\section{THE NATURE AND ROLE OF TREATIES}

Historically, the cornerstone of international law was the treaty. ${ }^{7}$ Sovereign states controlled the world, its people, commerce, information, and military might. Creation of rules by treaty became the international rules of conduct between nations. Up until 1990 or so, the countries of the world were the primary deciders of most international issues, but with the breakup of the Soviet Union and the coming of the technology revolution of the 1990s, the sovereign states have had an increasingly modest role in international issues. ${ }^{8}$ The growth of large international corporations and the communication capacity of the Internet have diminished the role of nation states in international affairs. ${ }^{9}$ This Article will discuss this topic more thoroughly below. For the moment, the focus will be on understanding what a treaty is and how it could be helpful for the wellbeing of animals.

A treaty is a formal written agreement between nation states, either bi-lateral or multi-lateral, which commits the states to engage, or not engage, in certain actions. ${ }^{10}$ Under the internationally accepted concept of sovereignty, the leaders of a country may choose any course of action internally or externally that they may wish. ${ }^{11}$ The leaders of a country may change their minds at will, but most find it in their best interests to restrict their freedom of action by becoming members of a treaty under which other countries also agree to restrict their freedom. Thus, while a country may believe it would be cheaper to dump chemical waste in other countries rather than treat the waste at home, most nation states have made the collective decision that this is a dangerous and unfair path to take. As a result, most countries have agreed to limit their freedom of action by signing the Basel Convention on the Control of Transboundary Movement of Hazardous Waste and their Disposal, which prohibits the dumping of certain waste in other countries. ${ }^{12}$

7 Id. at 591.

8 See generally, Thomas L. Friedman, The Lexus and the Olive Tree 200-02 (Farrar, Straus \& Giroux 1999) (describing the role that globalization has had in framing and shaping geopolitics).

9 Id.

10 Vienna Convention on the Law of Treaties pt. I, art. 2(a) (May 23, 1969) (available at http://www.unhcr.org/refworld/docid/3ae6b3a10.html (accessed Apr. 8, 2012)) [hereinafter Vienna Convention].

11 Michael Ross Fowler \& Julie Marie Bunck, Law, Power, and the Sovereign State: The Evolution and Application of the Concept of Sovereignty 11 (Pa. State U. Press 1995).

12 Basel Convention on the Control of Transboundary Movements of Hazardous Wastes and Their Disposal art. 4 (May 5, 1992), 28 I.L.M. 649 (available at http://www. basel.int/Portals/4/Basel\%20Convention/docs/text/BaselConventionText-e.pdf (updated Jan. 2011) (accessed Apr. 5, 2012)) ("Parties shall prohibit or shall not permit the export of hazardous wastes and other wastes to the Parties which have prohibited the import of such wastes."); United Nations Handbook 2011/12: An Annual Guide for those Working With and Within the United Nations 11 (49th ed., Ministry of For. Affairs \& Trade/ 
So long as a country is a member of a treaty, it is expected to conform to the treaty. ${ }^{13}$ Even if a new president is elected, a country nevertheless continues to be bound by all previously signed treatiesunless it formally withdraws from the treaty. ${ }^{14}$ For this reason, the creation of a treaty, and the decision to become a "member state" of a treaty, is recognized as a significant national event requiring a formal process. This is referred to as "the process of ratification." 15 While treaties do not dictate how a nation state decides whether to become a member of a treaty, they do have a process by which a nation state formally acknowledges the decision of ratification to other countries.

The United States, for example, ratified the treaty on global warming in October 1992, becoming a member state. ${ }^{16}$ However, when the Parties to the United Nations Framework Convention on Climate Change developed the Kyoto Protocol (Protocol) ${ }^{17}$ establishing emissions limitations for greenhouse gases so as to limit global warming, unlike the 192 nation states, which are Parties, the U.S. declined to ratify this Protocol. ${ }^{18}$ Therefore the U.S. is not bound by international law to restrict greenhouse gases. (Of course the U.S. could decide at any point to adopt any level of restriction that it might choose under the power of sovereignty.) As the U.S. is not a party to the Protocol, the U.S.'s national policy for economic development is not limited by the restrictions of the Protocol. An example of a significant multi-lateral treaty that the U.S. promoted internationally is the Convention on International Trade in Endangered Species and Wild Fauna and Flora (CITES). ${ }^{19}$ The obligations of the U.S. under this treaty-primarily to

Manatu Aorere 2011) (stating that 193 states existed in the United Nations as of July 15, 2011).

13 Anthony Aust, Modern Treaty Law and Practice 179-80 (2d ed., Cambridge U. Press 2007) ("Every treaty . . . is binding upon the parties to it and must be performed ....”).

$14 \mathrm{Id}$. at 288.

$15 \mathrm{Id}$. at 103 ("Ratification is defined ... as 'whereby a State establishes on the international plane its consent to be bound by a treaty."”).

$16 I d$.

17 Kyoto Protocol to the United Nations Framework Convention on Climate Change (Dec. 11, 1997) (available at http://unfccc.int/resource/docs/convkp/kpeng.pdf (accessed Apr. 8, 2012)) [hereinafter Kyoto Protocol]. For the difference between the Protocol and the Convention, see UN Framework Convention on Climate Change, Kyoto Protocol, http://unfccc.int/kyoto_protocol/items/2830.php (accessed Apr. 8, 2012) ("The major distinction between the Protocol and the Convention is that while the Convention encouraged industrialised countries to stabilize Green House Gas (GHG) emissions, the Protocol commits them to do so.") (emphasis added).

18 UN Framework Convention on Climate Change, Status of Ratification of the Kyoto Protocol, http://unfccc.int/kyoto_protocol/status_of_ratification/items/2613.php (accessed Apr. 8, 2012) ("Currently, there are . . 192 States . . . [party] to the Kyoto Protocol.”); U.N. Framework on Climate Change, Parties \& Observer States, http:// unfccc.int/parties_and_observers/parties/items/2352.php (accessed Apr. 8, 2012) (indicating that the U.S. is not listed among the parties to the Kyoto Protocol).

19 Convention on International Trade in Endangered Species of Wild Fauna and Flora (Mar. 3, 1973), 27 U.S.T. 1087, 993 U.N.T.S. 243 (available at http:// www.cites.org/eng/disc/text.php (accessed Apr. 8, 2012)) (also known as the Washington 
issue permits and restrict importation and exportation of listed, protected species-are implemented through the U.S. Endangered Species Act (ESA). ${ }^{20}$ To import or export a specimen of a species listed on a CITES appendix may require private parties to obtain government issued permits. ${ }^{21}$

It is important to understand that some international instruments are not treaties. Declarations are not treaties. ${ }^{22}$ Declarations may be public statements about something, but they do not bind States to actually do or stop doing anything. ${ }^{23}$ An example of this is the Universal Declaration on Animal Welfare (Declaration). ${ }^{24}$ This short declaration primarily states that countries should acknowledge that animal welfare is an important public policy issue and more needs to be done for the benefit of animals around the world. While a number of countries have acknowledged support of the document, it is not yet a formally accepted declaration. ${ }^{25}$ Whenever it may become an international declaration, it will not be considered a treaty. A review of the language of the Declaration makes it clear that any country associating itself with the Declaration is not actually committing itself to doing or refraining

Convention) [hereinafter CITES]; see generally U.S. Dept. Agric./Animal \& Plant Health Inspection Serv. (USDA/APHIS), Factsheet: The Convention on International Trade in Endangered Species of Wild Fauna and Flora (CITES), http://www.aphis.usda. gov/publications/plant_health/content/printable_version/fs_cites3-06.pdf (Mar. 2006) (accessed Apr. 8, 2012) (giving an overview of CITES, which was ratified in 1974).

2016 U.S.C. $\S \S 1531-1544$ (2010); 50 C.F.R. $§ 23.1$; see Pervaze A. Sheikh \& M. Lynne Corn, Cong. Research Serv., The Convention on International Trade in Endangered Species of Wild Fauna and Flora (CITES): Background and Issues CRS-9 (Feb. 1, 2005) (available at http://www.nationalaglawcenter.org/assets/crs/RL32751.pdf (accessed Apr. 8, 2012)) (“The [ESA] implements CITES in the United States.").

21 See Sheikh \& Corn, supra n. 20, at CRS-3 (explaining that Appendix I specimens require both an import and export permit for trade between Party nations); see generally USDA/APHIS, Import and Export, http://www.aphis.usda.gov/import_export/index.shtml (Aug. 4, 2011) (accessed Apr. 8, 2012) (providing information regarding animal and animal product import and export protocol).

22 Webster's Third New International Dictionary 2435 (Philip Babcock Gove et al. eds., Merriam Webster, Inc. 1993) (definition of a treaty includes "a contract in writing between two or more political authorities . . . formally signed by representatives duly authorized and usually ratified by the lawmaking authority of the state").

$23 I d$. at 586 (definition of a declaration includes "a statement or document proclaiming the principles, aims, or policy of a public body").

24 See Universal Declaration on Animal Welfare (Declaration), http://s3.amazonaws. com/media.animalsmatter.org/files/resource_files/original/Latest\%20draft\%20UDAW \%20Text\%20-\%202011.pdf?1314177486 (accessed Apr. 8, 2012) (copy of proposed Declaration, amended in 2011). For an explanation of the Declaration, see World Socy. for the Protec. of Animals, Universal Declaration on Animal Welfare, http://www.wspa-international.org/wspaswork/udaw/Default.aspx (accessed Apr. 8, 2012) [hereinafter WSPA].

25 WSPA, supra n. 24, at "What Can I Do?” (“[O]ver 2 million compassionate individuals, and many supportive governments-including Cambodia, Fiji, New Zealand, Palau, the Seychelles, Switzerland and the 27 European Union member states" have adopted the declaration.). 
from doing anything in particular. ${ }^{26}$ Likewise, declarations announced at economic summits do not have status as treaties, but instead are simple, feel-good statements about the current thoughts of countries that are represented at the meeting. ${ }^{27}$

The final point to make is that treaties are agreements only between sovereign nations. Within the U.S., the state of California, even though its population and economic activity might suggest it is as important as many countries, does not have the power to enter into a treaty. Neither may Apple, Inc. or Boeing make treaties; nor may the Humane Society of the U.S. or other non-profit organizations. In today's world, Bill Gates may have as much economic power, information, and ties to others with political power as any number of countries. ${ }^{28}$ Apple, Inc. has as much cash on hand as any number of countries. ${ }^{29}$ But that does not allow them to make treaties. With all these other sources of power in today's world, the importance of a treaty is more limited than it was in the past. However, a treaty can still be a powerful statement and motivator for action.

\section{THE NEED FOR AN ANIMAL WELFARE TREATY}

Many individuals and organizations around the world feel that the use of animals and the conditions under which many are kept are unacceptable and seek to enhance the protection and status of animals. ${ }^{30}$ They believe that animals are subjected to considerable pain,

\footnotetext{
26 See e.g. Universal Declaration on Animal Welfare, supra n. 24, at preamble, II 9 (acknowledging that "the provisions in this declaration do not affect the rights of any Member State").

27 See e.g. www.economicsummites.info, G20 Seoul Summit-Final Declaration, http://www.economicsummits.info/2010/11/g20-seoul-summit-final-declaration/ (Nov. 13, 2010) (accessed Apr. 8, 2012) (the statement released at the end of G20 Summit (meeting of the leaders of the twenty largest economies in the world) held in Seoul, South Korea in 2010 suggested a detailed course of action for economic protection and development). Note that this is a statement of what they think would be good to do and does not represent a legal commitment to, in fact, do what is stated.

28 Bill \& Melinda Gates Found., Annual Report. CEO Letter 4 (2010) (available at http://www.gatesfoundation.org/annualreport/2010/Documents/2010-annual-report-ceoletter-english.pdf (accessed Apr. 8, 2012)) (the Bill \& Melinda Gates Foundation had assets of $\$ 33.9$ billion at the end of 2009); see Forbes, Bill Gates, http://www.forbes.com/ profile/bill-gates/ (updated Mar. 2012) (accessed Apr. 8, 2012) (indicating that Bill Gates's personal wealth is estimated at $\$ 61$ billion in 2012).

29 Compare e.g. Apple, Inc., Annual Report 24 (2010) (available at http://files.shareholder.com/downloads/AAPL/1666106876x0xS1193125-11-282113/320193/filing.pdf (accessed Apr. 8, 2012)) (Apple Inc.'s total cash, cash equivalents, and marketable securities were $\$ 51.011$ billion in 2010) with Central Intelligence Agency, The World Fact Book, Country Comparison: GDP, https://www.cia.gov/library/publications/theworld-factbook/rankorder/2001rank.html (accessed Apr. 8, 2012) (showing all nations' estimated 2011 Gross Domestic Product (GDP). Apple had high enough sales in 2010 to rank 69th out of 226 countries and had more cash on hand than the total GDP of nine of the countries on the list.).

30 See e.g. Animal Welfare Online, Network, http://enextranet.animalwelfareonline. org/network/index.aspx (accessed Apr. 8, 2012) (global animal protection network, online magazine publication chronicling efforts of groups and individuals working for
} 
suffering, and death, much of which is not necessary or appropriate. The fact patterns under which the discussions arise are very diverse. How should pets be treated? If commercial animals are being transported, what conditions are appropriate for them? Should animals be used in research, testing, or educational settings? Which wild animals are acceptable for exhibiting and what standards should there be for the conditions of exhibits? These are not easy questions, but a horse is a horse regardless of what country it lives in, and it is not appropriate that it can receive high care in some places and no concern in others. For the wellbeing of the animals we need to seek a more universal view about how to treat animals.

The animals that would gain the most from an animal welfare treaty are agricultural animals. While within the European Union (EU), and Europe generally, some level of protection for animal welfare is provided, ${ }^{31}$ for most of the world there are very few legal limitations on the use of agricultural animals. Within the U.S. this is a particular problem. When introduced to commercial animals and issues of welfare, most students assume that some law must exist to provide a minimum level of protection for farm animals such as chickens. This is not the case. Most state anti-cruelty laws have a specific exemption for agricultural practices. ${ }^{32}$ For example, the Michigan anti-cruelty law has the following provision:

This section does not prohibit the lawful killing or other use of an animal, including, but not limited to, the following:

(a) Fishing.

(f) Farming or a generally accepted animal husbandry or farming practice involving livestock.

The language above would extend to hogs, cattle, and other animals, as well as chickens. A key issue in this area is what constitutes "traditional agricultural practices," as most statutory exemptions use this or an equivalent phrase. While apparently everyone can agree that starvation is not a "generally accepted farming practice," 33 it is unclear what the word "traditional" might mean: those practices used by the average producer or the high-volume producer; 100-year-old

animal rights); Humane Socy. of the U.S. (HSUS), About Us, http://www.humanesociety.org/about/ (2012) (accessed Apr. 8, 2012) (providing examples of individuals and organizations); WSPA, Who We Are, http://www.wspa-international.org/whoarewe/ Default.aspx (accessed Apr. 8, 2012).

31 See Nicholas K. Pedersen, Animal Leg. \& Historical Ctr., European Animal Welfare Laws 2003 to Present: Explaining the Downturn, http://www.animallaw.info/articles/ddeuanimalwelfare2009.htm (2009) (accessed Apr. 8, 2012) (providing insight and examples of EU animal welfare laws).

32 See e.g. Mich. Comp. Laws $§ 750.50 b(7)$ (2001) (providing examples of state anticruelty laws with exemptions for agricultural practices); Mo. Rev. Stat. Ann. $\S 578.007$ (8) (West 2009); Wash. Rev. Code Ann § 16.52.185 (West 2009).

33 See e.g. McClendon v. Story Co. Sheriff's Off., 403 F.3d 510, 513-14 (8th Cir. 2005) (a farm with thirty-seven horses was not providing adequate food and care); St. v. Klammer, 41 N.W.2d 451, 451-52 (Minn. 1950) (twenty-eight horses died of starvation); People v. Johnson, 305 N.W.2d 560, 561 (Mich. App. 1981) (four horses had been starved). 
practices or farming practices that are only twenty years old. State prosecutors seem entirely disinterested in pursuing with a jury trial what is or is not included in such exemptions. Therefore, state cruelty laws in the U.S. do not really provide welfare protection for commercial animals.

Even when the legislature seeks to act on behalf of agricultural animals, it does not always result in a beneficial outcome. In 1996, New Jersey took the progressive step of directing the state agricultural agency to adopt humane standards for the raising of agricultural animals. ${ }^{34}$ However, the regulations adopted were nearly identical to many of the existing industrial practices. ${ }^{35}$

In the U.S. we have one national law that touches upon animal welfare for a limited number of issues, the federal Animal Welfare Act. ${ }^{36}$ Under this law, the outcome for agricultural animals is no better at the federal level than at the state level. The Act specifically says that agricultural animals are exempt from its provisions. ${ }^{37}$

\section{A. The Lack of Existing International Law}

Considering existing international treaty law about animals requires dividing animals into the categories of wildlife and domestic. While among the European States there are a number of treaties that deal with domestic animal issues, ${ }^{38}$ there are no global treaties dealing with these issues. ${ }^{39}$ Wildlife on the other hand, with their natural tendency to move about regardless of national borders, are the subject matter of a number of treaties. The primary focus of these treaties is the preservation of endangered species or the management of commercial valuable species so that they will not become endangered. There are a number of treaties dealing with migratory birds and fish ${ }^{40}$ and the International Convention for the Regulation of Whaling deals with

\footnotetext{
34 N.J. Stat. Ann. $\S \S 4: 22-16.1$ (West 1998).

35 N.J. Socy. for the Prevention of Cruelty to Animals v. N.J. Dept. of Agric., 955 A.2d 886, 907-16 (N.J. 2008).

367 U.S.C. $\$ \S 2131-2159$.

377 U.S.C. $\$ 2132$ (g) (Supp. 2000) (“The term 'animal' means any live or dead dog, cat, monkey (nonhuman primate mammal), guinea pig, hamster, rabbit, or such other warm-blooded animal . . but such term excludes . . (2) horses not used for research purposes, and (3) other farm animals, such as, but not limited to livestock or poultry, used or intended for use as food or fiber, or livestock or poultry used or intended for use for improving animal nutrition, breeding, management, or production efficiency ....”).

38 See Pedersen, supra n. 31.

39 WSPA, Animal Protection Legislation pt. 8 (2006) (available at http://enextra net.animalwelfareonline.org/resources/animalwelfare/legislation/index.aspx, select An Overview of Animal Protection Legislation, scroll down to Part 8: International Conventions and Agreements (accessed Apr. 8, 2012)).

40 See generally P. van Heijnsbergen, International Legal Protection of Wild Fauna and Flora (IOS Press 1997) (cataloging the international legal instruments which have their main goal as the protection of wild fauna or flora).
} 
whales. ${ }^{41}$ The welfare of individual wildlife is not normally the focus of these treaties. ${ }^{42}$

One exception to the lack of concern for the welfare of wildlife is a provision within the Convention on International Trade in Endangered Species and Wild Fauna and Flora (CITES). ${ }^{43}$ Article III, paragraph 2(c) and Article IV, paragraph 2(c) states the requirements for granting an export permit of live wildlife protected by the treaty: "[T]he State of export is satisfied that any living specimen will be so prepared and shipped as to minimize the risk of injury, damage to health or cruel treatment." 44 Satisfaction of this requirement is normally met by simply agreeing to abide by the shipping standards adopted by International Air Transport Association. ${ }^{45}$ The countries that are Parties to CITES have not explicitly defined what constitutes cruel treatment. ${ }^{46}$ Also, attempts to extend this welfare concern to the capture and holding of wildlife during the domestic portions of travel, rather than solely relying on the broader international component to address more local concerns, have failed. ${ }^{47}$

More representative of present treaties is the Convention on Biological Diversity, which seeks to promote the protection of the environment and the wildlife contained therein, but says nothing about the welfare of individual animals. ${ }^{48}$ Thus, it is clear that while the environmental perspective of the importance of wildlife as part of ecosystems is well accepted, the conditions of life and death of individual animals at the hands of humans around the world are not yet a focus of legal drafting.

\section{B. The International Movement of Animals}

Animals move internationally, slipping from one jurisdiction and set of laws to another; from full protection in one country to little or no protection in another. For all practical purposes the slaughter of horses in the U.S. for food has been eliminated; now horses are exported to be slaughtered in Mexico, where the conditions of the slaughterhouse are not as regulated as in the U.S. This outcome might make some of the people in the U.S. feel better, but it is not a better outcome for the

41 International Convention for the Regulation of Whaling art. IV (Dec. 2, 1946), http://iwcoffice.org/_documents/commission/convention.pdf (accessed Apr. 8, 2012) [hereinafter International Whaling Convention]; see generally Intl. Whaling Commn., http://iwcoffice.org/ (updated Dec. 10, 2011) (accessed Apr. 8, 2012) (the homepage for the International Whaling Commission).

42 International Whaling Convention, supra n. 41, at art. VIII.

43 CITES, supra n. 19

$44 \mathrm{Id}$. at art. III, II 2(c), art. IV, II 2(c).

45 Transport of Live Specimens, CITES Resolution Conf. 10.21, (1997) (rev. CoP14) (available at http://www.cites.org/eng/res/10/10-21R14.php (accessed Apr. 8, 2012)).

46 CITES, supra n. 19, at art. I (not including a definition of "cruel treatment").

47 Michael Bowman et al., Lyster's International Wildlife Law 691-92 (2d ed., Cambridge U. Press 2010).

48 Convention on Biological Diversity art. 8 (May 21, 1992), http://www.cbd.int/convention/articles/?a=cbd-08 (accessed Apr. 8, 2012). 
horses that are shipped to Mexico. The laws of the U.S. for horse protection are frustrated since other countries do not have equal laws of protection and the horses can be easily transported to other countries.

Whales and sharks move globally on their own volition. Some countries, particularly in Asia, use the fins of a shark to make soup that is in high consumer demand as a prestige food. ${ }^{49}$ This demand results in the cutting off of the fin of live sharks resulting ultimately in pain, suffering, and death. ${ }^{50}$ Other countries have judged that the consumption of the soup does not justify the pain, suffering, and death of the sharks and prohibit the practice. ${ }^{51}$ Depending on where sharks are swimming, they will either be protected or subject to cruel deaths.

Another international issue is the live shipment of livestock from countries like Australia to the Middle East, because of a preference for local slaughter rather than frozen meat. ${ }^{2}$ Even though Australians may have good laws for the welfare of livestock within their borders, conditions on the high seas and treatment at the import country are not under the same welfare standards. ${ }^{53}$ It is not clear whether this use of agricultural animals should be allowed at all, let alone what might constitute acceptable welfare conditions.

An animal welfare treaty would be one method of seeking a broader global consensus on how a particular species of animal should be used, and, if a use is acceptable, what level of welfare must be provided during the use.

\section{Fostering Discussion and Consensus}

Within a particular country, it is often the case that citizens, citizen groups, and nongovernmental organizations have a concern about a variety of animal welfare issues, but it is very difficult to get the attention of the national government to address these issues. ${ }^{54}$ The creation of an international discussion about the possibility of an animal welfare treaty will provide space for conversations on the national level. The adoption of such a treaty will necessarily impose some level of obligation on countries to modify existing laws or adopt new

49 Save the Blue, Shark Campaign, http://savetheblue.org/sharks.html (accessed Apr. 8, 2012).

50 Socy. for the Prevention of Cruelty to Animals (H.K.), Shark Finning: The Facts, http://www.spca.org.hk/sharksfin/eng/stop_sharks_fin_soup_facts.html (accessed Apr. 8, 2012).

51 Shark Alliance Org., Closing the Loopholes on Shark Finning (Apr. 9, 2010) (available at http://sharkalliance.org/do_download.asp?did=35202 (accessed Apr. 8, 2012)).

52 Austrl. Gov. Dept. of Agric., Fisheries \& Forestry, Live Export Trade-Middle East: Frequently Asked Questions, http://www.daff.gov.au/_data/assets/pdf_file/0005/ 435281/live-trade-faqs.pdf (accessed Apr. 8, 2012).

$53 I d$.

54 Colin Kreuziger, Dismembering the Meat Industry Piece by Piece: The Value of Federalism to Farm Animals, 23 L. \& Inequal. 363, 378 (2005) ("State and federal legislation remain largely unconcerned with the plight of farm animals. Given this indifference, a number of organizations respond to the problem of cruel farmed-animal practices in a variety of ways."). 
laws. This will provide political leverage for individuals and organizations to raise internal issues with their governments and foster a public discussion about what the laws ought to be.

Additionally, within the U.S., the existence of a treaty would bring federal jurisdiction to what is otherwise now primarily a state jurisdictional issue. ${ }^{55}$ At the moment, under the U.S. Constitution, the only jurisdiction for animal welfare issues arises indirectly out of the power of the federal government to control international and interstate commerce. ${ }^{56}$ However, the federal government is fully empowered to engage in the treaty process, and, once that is done, the federal government has jurisdiction over the subject matter of the treaty for purposes of implementation. ${ }^{57}$ For example, CITES gives the federal government the power and duty to implement domestic legislation for the protection of endangered species. ${ }^{58}$ Likewise, the discussion of the International Convention for the Protection of Animals will raise important animal issues in a national, federal debate. Whether this will be positive or negative for the animals of the U.S. cannot be known at this point in time.

\section{Reducing Negative Economic Incentives}

A critical reason for a treaty is the reality of global corporations that operate internationally and that seek to make a profit off of animals and animal products. These corporations have concern for the welfare of the animal in only three circumstances: the buyers demand it, it has a negative effect on the profit of the corporation, or the law requires it. Under the rules of capitalism, usually the least cost producer of a product will receive increased market share and higher profits. ${ }^{59}$ To the extent that a single country seeks to enhance the welfare of agricultural animals, corporations may seek to avoid the cost of increased animal welfare measures by raising the animals in another country. Even if a corporation seeks to do a better job of caring for its animals, it risks losing market share-and potentially going out of business-because other corporations can operate more cheaply without welfare measures. Unrestrained economic competition will always impose the most inhumane conditions on the animals within the system, as they tend to be the cheapest management practices. If there

55 Kerr v. Kimmell, 740 F. Supp. 1525, 1530 (D. Kan. 1990).

56 U.S. Const. art. I, § 8, cl. 3.

57 Mo. v. Holland, 252 U.S. 416, 434 (1920) ("Valid treaties of course are as binding within the territorial limits of the States as they are elsewhere throughout the dominion of the United States. No doubt the great body of private relations usually fall within the control of the State, but a treaty may override its power.").

58 CITES, supra n. 19, at arts. VIII, XIV.

59 William Boulding \& Richard Staelin, Environment, Market Share, and Market Power, 36 Mgmt. Sci. 1159, 1159-60 (1990) ("Extensive documentation exists for the stylized fact of a positive relationship between profitability . . . and market share." Also important in the equation is low producer costs per unit of sales which result in higher profit margins.). 
were worldwide standards for animals within commerce that assured a cruelty-free life for animals, then the forces of capitalism would accept this as a base and seek the least cost products within that set of rules.

Even if a country could reach political consensus on enhanced protection for farm animals and adopt protective legislation, it may not be able to affect the conditions that exist outside the borders of that country. As an analogous example, consider that while American laws protect American children from child labor abuses, the U.S. is not in a position to prohibit the importation of items made by children in other countries that violate our labor standards. The result is that products overseas made with cheaper labor compete with products made in the U.S. There is no reason to think that the same pattern would not come into play if the U.S. laws for animal welfare increased product cost in this country while other countries did not change their law.

State sovereignty is a fundamental concept that permits these different conditions, whether of child labor or animal welfare. Under this long-standing international legal concept, it is accepted that each country has the right to decide what level of protection to give its citizens, animals, or environment. ${ }^{60}$ No one country has the right to enforce its standards on another country. Under this principle, a country may set up all sorts of barriers to trade coming into their country. The counterpoint to that perspective is found in free traders who believe that maximum wealth production on a global basis will occur when there are no barriers to the movement of goods between countries. ${ }^{61}$

This conflict of principles between sovereign protectionism and free trade is front and center in the World Trade Organization (WTO) and associated treaties. ${ }^{62}$ At the moment, this regime may be the most important legal framework regarding animals as it controls international trade of live animals and animal products, such as meat and skins. ${ }^{63}$ One hundred and fifty-three countries are members of this treaty. ${ }^{64}$ With Russia's recent accession to the WTO, Iran remains the

60 John H. Jackson, The World Trading System: Law and Policy of International Economic Relations 232-33 (2d ed., MIT Press 1997).

61 Richard D. Wolff \& Stephen A. Resnick, Economics: Marxian Versus Neoclassical 40 (Johns Hopkins U. Press 1987).

62 See WTO, WTO ... Why it Matters: A Guide for Officials, Legislators, Civil Society and All those Interested in International Trade and Global Governance 17-18, http:// www.wto.org/english/thewto_e/minist_e/min01_e/wto_matters_e.pdf (accessed Apr. 8, 2012).

63 Agreement on Agriculture (Apr. 15, 1994), http://www.wto.org/english/docs_e/legal_e/14-ag.pdf (accessed Apr. 8, 2012); Agreement on Technical Barriers to Trade (Apr. 15, 1994), http://www.wto.org/english/docs_e/legal_e/17-tbt.pdf (accessed Apr. 8, 2012); General Agreement on Tariffs and Trade (Oct. 30, 1947), http://www.wto.org/english/ docs_e/legal_e/gatt47_e.pdf (accessed Apr. 8, 2012) [hereinafter GATT].

64 WTO, Understanding the WTO: The Organization: Members and Observers, http:// www.wto.org/english/thewto_e/whatis_e/tif_e/org6_e.htm (accessed Apr. 8, 2012); Pascal Lamy, Dir.-Gen. of the WTO, Speech, Stand Up for the Values of Multilateralism (Geneva, Eighth WTO Ministerial Conf. Dec. 15, 2011) (copy of transcript available at http://www.wto.org/english/news_e/sppl_e/sppl212_e.htm (accessed Apr. 8, 2012)); Press Release, Eur. Commn., EU Welcomes 3 New Members to the World Trade Organisation, 
only major country not part of the treaty. ${ }^{65}$ Unfortunately, "animal welfare" is not a phrase found in the treaty. 66

A full discussion of the workings of the WTO is not possible in this article. ${ }^{67}$ Consider these issues: whether the EU may ban the importation of seal skins because of the methods of death carried out in Canada;68 and whether the U.S. may restrict the importation of tuna from Mexico or the Philippines if dolphins have been killed in the process of catching the tuna. ${ }^{69}$ In both of these examples, one country is asserting its standards against the sovereign power of another country to decide when and how to kill animals. Promotion of free trade under the WTO umbrella is advanced by the general principle that it is illegal to restrict the importation of a product based on its method of production. ${ }^{70}$ Thus, the manufacturing of soccer balls with child labor would not be a justification that the U.S. could use to ban the importation of soccer balls manufactured in another country. Nor would the creation of industrial pollution in a country justify the imposition of trade bans by another. Under this general principle, if New Zealand passes a law requiring that only eggs from free-range chickens be sold, this provision might be a breach of WTO obligations for eggs from caged chickens that Australia seeks to import into New Zealand. ${ }^{71}$ However-and it is a big however-under the specific treaty establishing this principle, the General Agreement on Tariffs and Trade (GATT), there are exceptions and arguments that can be made that animal welfare concerns may qualify to justify limitations of trade between countries. ${ }^{72}$

Another exception to the provisions of the WTO is when a nation state carries out the requirements of another multilateral treaty. ${ }^{73}$ If

IP/11/1548 (Dec. 15, 2011) (available at http://europa.eu/rapid/pressReleasesAction.do? reference $=\mathrm{IP} / 11 / 1548$ (accessed Apr. 8, 2012)).

65 WTO, Ministerial Conference Approves Russia's WTO Membership, http://www. wto.org/english/news_e/news11_e/acc_rus_16dec11_e.htm (Dec. 16, 2011) (accessed Apr. 8, 2012).

66 A.B. Thiermann \& S. Babcock, Animal Welfare and International Trade, 24 (2) Rev. Sci. Tech. Off. Int. Epiz. 747, 747 (2005).

67 See generally Kelch, supra n. 2, at ch. 7 (chapter discussing the WTO).

$68 \mathrm{Id}$. at 254.

69 See generally id. at 251 (describing the debate surrounding the U.S.'s ban of tuna and the WTO Appellate Body ruling on the issue in Tuna/Dolphin I).

$70 I d$. (this is also known as "process or production method" which is set out specifically in Article III:4 of the GATT stating that imported "products . . . shall be accorded treatment no less favorable than that accorded to like products of national origin").

71 Id.

$72 I d$. at 256 (stating that in Article XX of the GATT there are three basic exceptions to the substantive provisions that could potentially be utilized to allow the regulation of animal welfare. The exceptions are restrictions that are: (1) necessary to protect public morals; (2) necessary to protect human, animal, or plant life or health; or (3) relating to the conservation of exhaustible natural resources.).

73 Vienna Convention, supra n. 10, at pt. III, art. 30 (stating that when all of the parties to one treaty are also parties to a subsequent treaty, the original treaty only applies to the extent that its provisions are compatible with those of the later treaty). 
the ICPA is subsequently adopted-prohibiting the sale of eggs from caged hens- countries adopting that ban in domestic law would not be in violation of WTO responsibilities. Any subsequently adopted animal welfare treaty will supersede the restrictions of the GATT, thus allowing the use of trade import restrictions to enforce international obligations. ${ }^{74}$

\section{E. Default Standards of OIE Are Not Sufficient}

There is one international body that is seeking to create international standards for animal welfare issues: the World Organization for Animal Health, known as OIE. ${ }^{75}$ OIE is an international organization created by an international agreement between twenty-eight countries in 1924 to deal with issues of animal health, ${ }^{76}$ particularly those in international trade where the risk of disease can transfer from one country to another. ${ }^{77}$ Presently there are 178 countries that are members of this international organization. ${ }^{78}$

The human delegates to the body tend to be from the national veterinary administration or the agricultural administration of a country. ${ }^{79}$ They have adopted a detailed and science-based process for the adoption of sanitary standards. ${ }^{80}$ These standards are not immediately binding on the Parties, but are recommendations for them to follow. ${ }^{81}$ These standards are significantly enhanced by the fact that they

74 Id.

75 See World Org. for Animal Health, The OIE's Achievements in Animal Welfare, http://www.oie.int/animal-welfare/animal-welfare-key-themes/ (accessed Apr. 8, 2012) (stating that animal welfare was identified as an OIE priority in OIE Strategic Plan 2001-2005).

76 World Org. for Animal Health, History, www.oie.int/about-us/history/ (accessed Apr. 8, 2012) (stating that the OIE was created in 1924).

77 See World Org. for Animal Health, Objectives, www.oie.int/index.php?id=53c201 (accessed Apr. 8, 2012) (The OIE develops normative documents relating to rules that Member Countries can use to protect themselves from the introduction of diseases and pathogens, without setting up unjustified sanitary barriers. The main normative works produced by the OIE are: the Terrestrial Animal Health Code, the Manual of Diagnostic Tests and Vaccines for Terrestrial Animals, the Aquatic Animal Health Standards Code and the Manual of Diagnostic Tests for Aquatic Animals.); see also Kelch, supra n. 2, at 266 (stating that "historically, the OIE has focused on issues relating to disease prevention and sanitary standards for animals and animal products in international trade").

78 World Org. for Animal Health, The 178 OIE Members, www.oie.int/about-us/ourmembers/member-countries/ (accessed Apr. 8, 2012).

79 World Org. for Animal Health, The 178 Permanent Delegates of the OIE, http:// www.oie.int/about-us/our-members/delegates/\# (accessed Apr. 8, 2012) (For example, France's delegate, Dr. Jean-Luc Angot, is Associate Director General of Food at the Ministry of Agriculture and Fish, and Ireland's delegate, Dr. Martin Blake, is Chief Veterinary Officer at the Ministry of Agriculture, Marine and Food.).

80 World Org. for Animal Health, Procedures Used by the OIE to Set Standards and Recommendations for International Trade, with a Focus of the Terrestrial and Aquatic Animal Health Codes, http://www.oie.int/en/international-standard-setting/overview/ productionimplementation/ (accessed Apr. 8, 2012).

81 Kelch, supra n. 2, at 267 (stating that standards are in the form of recommendations "typically using 'should' language"). 
are recognized by the WTO system and may be the basis for international trade restrictions. ${ }^{82}$

Since 2001, the organization has also decided to take upon itself the development of animal welfare standards. ${ }^{83}$ While the issues of animal health are strongly based upon scientific information, issues of animal welfare are public policy decisions, not science-based decisions. Therefore, this organization is not the best place to address the difficult questions of the quality of life for animals versus the economic and social consequences of imposing limitations on the use of animals. Likewise, a science-based organization should not be empowered to set environmental standards. Rather the role of science is to inform the decision makers of present facts and possible future consequences of alternative causes of action.

A review of the adopted OIE standards on live animal transport will reveal their significant limitations. ${ }^{84}$ The standards include no numbers, no prohibitions, no required inspections, and no limitations on operations. ${ }^{85}$ Rather, the standards read like a checklist of issues that should be considered if you are going to engage in live animal transport. While this list is useful for policy makers, it is not an actual standard that limits or prohibits practices that are harmful to animal welfare, nor can it be expected to do so as OIE not charged with such an important responsibility. Therefore, the existence of this organization does not diminish the need for an international animal welfare treaty that directly seeks to deal with issues of public policy.

\section{HOW TO BUILD AN ANIMAL WELFARE TREATY}

An International Animal Welfare Treaty should utilize an umbrella treaty approach. The first step is to draft a framework treaty with the intent to further refine and resolve specific welfare issues in subsequent protocols. A model treaty has already been drafted and currently the most crucial issue facing its adoption is the absence of a country to sponsor the treaty. Necessary provisions for an umbrella

82 WTO, Agreement on the Application of Sanitary and Phytosanitary Measures, app. A(3)(b), 77, http://www.wto.org/english/docs_e/legal_e/15sps_02_e.htm (accessed Apr. 8, 2012) (specifically recognizing the "animal health and zoonoses, the standards, guidelines and recommendations developed under the auspice of the International Office of Epizootics." In general the Agreement supports the use of these trade restrictions by invoking the Article XX(b) exception of the GATT.).

83 Kelch, supra n. 2, at 266 (stating "[t]he OIE Strategic Plan of 2001-2005, however, identified animal protection as a priority of the organization and the OIE has begun creating international standards of animal welfare").

84 World Org. for Animal Health, Terrestrial Animal Health Code Transport of Animals by Sea (OIE 2011) (available at http://www.oie.int/index.php?id=169\&L=0\&htm file=chapitre_1.7.2.htm (accessed Apr. 8, 2012)).

85 See e.g. id. at 3 (Article 7.2.3: Responsibilities 2(a)(iii) states that "securing the presence of the appropriate number of animal handlers competent for the species being transported" does not provide specific numbers of handlers per animal, does not give any limitation on what would qualify as an "appropriate number" and relies on a vague "competent" standard). 
treaty are discussed in relation to the chosen language in the International Convention for the Protection of Animals (ICPA) and the companion protocols.

\section{A. The Nature of Umbrella Treaties}

When faced with large and complex problems that impact all countries, it is often difficult to obtain consensus on specific answers to problems and concerns even when there is general agreement that a problem exists and ought to be addressed. During the early 1990s the global community began to realize that the negative impacts on the planet arising out of the number and consumption patterns of humans were causing serious global problems. ${ }^{86}$ There was considerable political energy to move toward treaty agreements that address a number of these broad issues. The United Nations body, United Nations Environment Programme (UNEP), oversaw the Rio Summit in Rio de Janeiro, Brazil in June 1992. At this summit, two umbrella treaties were adopted: the Convention on Biological Diversity (CBD) and the UN Framework Convention on Climate Change (UNFCCC). 87

For both treaties, the vast majority of states agreed that (a) increasing greenhouse emissions represented a risk of global warming, and (b) that present human patterns of consumption and land use were destroying the natural ecosystems around the world. ${ }^{88}$ However, there were serious disagreements about who was responsible for the problems, who would accept responsibility for solving the problems, and even how they would be solved. ${ }^{89}$ This Article is not the place to relive those debates. Rather, it is useful to consider the structures of

86 See generally David Hunter et al., International Environmental Law and Policy 47 (4th ed., Found. Press 2011) (discussing consumption and stating that the primary concern raised by expansive population growth and consumption is the environmental impact).

87 Michael Grubb et al., The Earth Summit Agreements: A Guide and Assessment 13-16 (Earthscan Publications Ltd. 1993). An "umbrella treaty" is essentially another name for a "framework agreement," in which the parties "acknowledge the existence of a problem or threat, and commit to cooperative action, without undertaking substantive obligations." Hunter et al., supra n. 86, at 356; see generally e.g. John A. C. Cartner \& Edgar Gold, Q.C., Commentary in Reply to "Is It Time for the United States to Join the Law of the Sea Convention", 42 J. Mar. L. \& Com. 49, 63 (2011) (demonstrating the interchangeability of the two terms by defining the Law of the Sea Convention as "a global framework or umbrella treaty beneath which other 'competent organizations' . . could develop more specific international legislation").

88 UN, Framework Convention on Climate Change, Preamble http://unfccc.int/essential_background/convention/background/items/1350.php (accessed Apr. 8, 2012) [hereinafter UNFCCC, Preamble] (the Parties affirmed that "human activities have been substantially increasing the atmospheric concentrations of greenhouse gases . . . and that this will result on average in an additional warming of the Earth's surface and atmosphere and may adversely affect natural ecosystems"); Convention on Biological Diversity, supra n. 48, at Preamble (stating that the parties were "concerned that biological diversity is being significantly reduced by certain human activities").

89 See Hunter et al., supra n. 86, at 154-56, 160 (describing the debate between the Global North and South). 
these adopted treaties and how each was intended to lead to future agreements about difficult issues.

Again, an underlying policy point is the right of a sovereign state to control its own destiny. ${ }^{90}$ Most nation states are very reluctant to enter into a treaty whereby they could be restricted in their future actions and policy by a majority vote of other Parties. The concept of majority rule, as accepted within the U.S. political system, is normally rejected as a basis for treaty decision making. ${ }^{91}$ A treaty that created an assembly that could, by majority vote, impose restrictions on energy development or require the setting aside of $10 \%$ of a country's land as national parks, would not be acceptable as it could give rise to violations of the countries' right of self-direction. But, a country might well agree to become part of an organization that would seek to solve problems and make recommendations in future legal documents that would contain specific restrictions. ${ }^{92}$ These future legal documents that would arise out of the discussions of the primary treaty body can be referred to as protocols of an umbrella treaty..$^{93}$

A protocol, which can be thought of as a mini-treaty, ${ }^{94}$ must be ratified by Parties just like a full treaty. Therefore, each country would have the sole right to decide whether or not to be part of the protocol. ${ }^{95}$ While the CBD has generated two subsequent protocols, ${ }^{96}$ the classic example of a protocol is the Kyoto Protocol, under the UNFCCC. ${ }^{97}$ A future goal that was reflected in the language of the initial umbrella treaty was the adoption of specific emissions limitations by the developed countries of the world. ${ }^{98}$ After an additional five years of negotia-

90 See e.g. id. at 1001 (describing how Convention on Biological Diversity negotiations centered around how to ensure biodiversity conservation with the least amount of infringement on sovereignty).

91 Paul C. Szasz, General Law-Making Processes, United Nations Legal Order vol. 1, 35, 85 (Oscar Schachter \& Christopher C. Joyner eds., U. Cambridge 1995).

$92 \mathrm{Id}$. at 92 (stating that one way to simplify the treaty process is "the use of framework or umbrella conventions that merely state general obligations and establish the machinery for the further norm-formulating devices").

$93 I d$. (stating that umbrella conventions are supplemented by the adoption of individual protocols "establishing particular substantive obligations in implementation of the general objectives of the convention"); Hunter et al., supra n. 86, at 295-96 ("[P]rotocols build on the parent agreement through the elaboration of additional (more specific) commitments and institutional agreements.").

94 A mini-treaty is a document that has the characteristics of a treaty even though it is not free standing but rather represents a small subtopic under the umbrella treaty.

95 Hunter et al., supra n. 86, at 295-96.

96 The Cartagena Protocol on Biosafety to the Convention on Biological Diversity (Jan. 29, 2000), http://bch.cbd.int/protocol/ (accessed Apr. 8, 2012) (international agreement which aims to ensure the safe handling, transport and use of living modified organisms (LMOs)); see generally The Nagoya Protocol on Access and Benefit-Sharing to the Convention on Biological Diversity (Oct. 29, 2010), http://www.cbd.int/abs/ (accessed Apr. 8, 2012) (international agreement which aims at sharing the benefits arising from the utilization of genetic resources in a fair and equitable way).

97 Kyoto Protocol, supra n. 17.

98 UNFCCC, Preamble, supra n. 88, at art. 4, sec. 2(a). 
tions, at a formal meeting in Kyoto, the Protocol was agreed upon. ${ }^{99}$ Most developed countries formally ratified the Protocol, agreeing to comply with the limitations. ${ }^{100}$ However, the U.S., which had been a significant part of the negotiation process, declined to ratify the agreement. ${ }^{101}$ The Protocol went into effect without the U.S. being bound by it even though it was a member of the umbrella treaty. ${ }^{102}$ The U.S. exercised its sovereign right and decided not to be a part of the Protocol.

The same reasons that supported the adoption of the environmental umbrella treaties in the 1990s support the approach of the umbrella treaty for the ICPA this decade. International rules for animal welfare are a new topic on the global scale, and many countries would be concerned about what this might mean in the future. Although a number of countries might agree that animal welfare is a problem that should be addressed, there is no consensus on what the outcome should look like. The creation of a formal dialogue process is a positive step forward. However, there may be some broad points of policy that could be agreed upon and, wherever possible, these should be sought out and reduced to a written provision. Thus, the proposal set out in Parts VI and VII contains the ICPA and an example of a protocol. The ICPA stipulates that any state who joins the treaty must also become a member of at least one protocol. ${ }^{103}$ Whether this approach would survive the actual negotiations is not known, but as the topic is a new one for international relations (e.g., who at the U.S. State Department would take the lead for such a treaty negotiation is unknown), it is also important to set out some level of detail so the direction and scope of the treaty can be better understood.

\section{B. Development of Draft Treaty}

During the 1980s, this author attended a number of the international meetings of the Party States to the Convention on International Trade in Endangered Species (CITES) as a representative of the Animal Legal Defense Fund. While in attendance, I met a delegate, named Bill Clark. We both decided at some point that an animal welfare treaty was needed as it became clear CITES was not interested in

99 Hunter et al., supra n. 86, at 677.

100 See UN Framework Convention on Climate Change, Status of Ratification of the Kyoto Protocol, http://unfccc.int/kyoto_protocol/status_of_ratification/items/2613.php (updated 2012) (accessed Apr. 8, 2012) (full list of Kyoto Protocol parties, showing that most countries have ratified the protocol).

101 Hunter et al., supra n. 86, at 696.

102 See id. at 695-96 (stating that the Protocol is now effective and in its first commitment period).

103 While only the Companion Animal Protocol is included within this Article, three others are available online. International Convention for the Protection of Animals (ICPA) art. 11, cl. 1 (unadopted, proposed April 4, 1988), http://animallaw.info/treaties/ itconfprotanimal.htm (accessed Apr. 8, 2012) ("No State may become a Contracting Party to this Convention unless it becomes a Contracting Party to at least one of the protocols at the same time."). 
such a topic. A committee was formed, and a draft produced. Two public hearings were held: one in Geneva, Switzerland and one in London, England. Once a polished draft evolved, it became clear that an international sponsor was required to give the treaty international attention. We asked to be put on the agenda of a Board meeting of World Society for the Protection of Animals, attended a meeting in Paris, and presented the treaty. They were not interested. In the early 1990s, we were joined by another person from the United Kingdom, who had higher visibility and political connections. With this person's efforts, an approach was made to a particular country as to their willingness to be a state sponsor of the treaty, but after some careful deliberations, they declined to go forward with the treaty. So, here it sits without an international sponsor that has the resources to start the process. It is prepackaged and ready to go.

\section{Suggested Language}

In drafting the language of the proposed treaty, a number of concerns had to be balanced against each other, as the treaty must: attract the most countries possible; provide provisions that would actually promote animal welfare, sooner rather than later; allow for some enforcement mechanism that has consequences but will not prevent countries from joining the treaty; provide for future development by creating a community of individuals seeking consensus of policy; provide for information gathering and sharing about present practices; and support transparency that allows non-government actors to be included, even if they do not have a vote at the end of the process. ${ }^{104}$

Generally, treaties have clusters of expected provisions: words of general policy, definitions of key words, substantive provisions, procedural provisions for ongoing concerns, and provisions that will define the starting point of the treaty. ${ }^{105}$ The words of general policy are in the Preamble of the treaty. ${ }^{106}$ They simply set the stage for the treaty, usually suggesting the need that gave rise to the treaty. As a rule, preamble language does not create any obligations for nation states. ${ }^{107}$ In the draft, ICPA Article 1's Fundamental Principles also do not create specific obligations but can be used to interpret the obligations found elsewhere in the treaty. ${ }^{108}$

Article 2 contains some key definitions. Definitions often represent political compromise for the scope of the treaty. Thus "animal" is defined as "any nonhuman mammal, bird, reptile, amphibian or fish and any other organisms which may be included specifically within a

104 Id. at art. 17.

105 Aust, Modern Treaty Law and Practice, supra n. 13, at 420.

106 Hunter et al., supra n. 86, at 304.

107 Black's Law Dictionary 1294-95 (Bryan A. Garner ed., 9th ed., West 2009) (defining "preamble" as "[a]n introductory statement ..." explaining the document's basis and objective).

108 ICPA, supra n. 103, at art. 1. 
particular protocol."109 Obviously the biological definition of animal would be much broader, but this is more likely the most that global concerns would support. While lobsters and octopuses are very interesting, they are unlikely to support a broader definition of the term animal at the international level. But if other specific species outside this broader definition gain political support for consideration, it could be achieved within the context of a particular protocol.

Articles 4 to 9 contain policy positions for particular categories of use by humans. ${ }^{110}$ This approach represents a compromise. Many individuals may believe that a rabbit should be treated the same regardless of the category of use that a particular rabbit might find itself: as a pet, food animal, scientific research subject, or game animal. But the laws around the world have been crafted with a focus on the categories of use. ${ }^{111}$ It is not possible to think that this perspective could be changed on a global basis. Also, the reality is that the political process will not accept equality of all rabbits, as the value of the human use will be weighed differently between rabbit categories, thus resulting in different outcomes for the particular rabbits. The language of these sections seeks the reduction of cruelty, but admittedly within the context of the use in question.

The substantive provisions of the Treaty are found in Articles 10 through 13.112 Each party agrees to designate an administrative agency to deal with treaty issues. While this may seem very minor, it is imperative to the goals of the treaty. If there is no authorized agency within a government, then there is no focus for the implementation of the treaty. No one will care if the treaty is fulfilled. Agencies propose budgets to implement programs and that will be necessary to realize treaty goals ${ }^{113}$ The other obligation represents a political judgment about how to best structure the treaty and its protocols. Understanding that, in all likelihood, not every country will have equal political support to engage all of the possible topics and that some commitment to change is desirable at the beginning of the treaty, a nation state

109 Id. at art. 2.

110 Id. at arts. 4-9 (referencing: Art. 4: Wildlife Management and Habitat; Art. 5: Captive Wildlife Car; Art. 6: Transportation of Animal; Art. 7 Companion Animals; Art. 8 Commercial Animals; and Art. 9: Animals Used in Scientific Research).

111 See generally General Law on the National Service of Animal Health, 8495 (2006) (Costa Rican law organizing the Veterinary Official Service of Costa Rica and focusing on preserving food safety though animal health); Performing Animals Protection Act of 1935, at 24 (South African law for regulating "the exhibition and training of performing animals and the use of dogs for safeguarding").

112 ICPA, supra n. 103, at arts. 10-13 (referencing: Art. 10: General Undertakings; Art. 11: Relationship Between the Convention and Protocols; Art. 12: Adoption of Additional Protocols; and Art. 13: Designation of Responsible Authority).

113 See e.g. 16 U.S.C. § 715(a) (West 2010) (provision titled: Migratory Bird Conservation Commission: creation; composition; duties; approval of areas of land and water recommended for purchase or rental; setting out a protocol for maintaining the Migratory Bird Treaty and the Migratory Bird Treaty Act by delegating management responsibilities to the U.S. Environmental Protection Agency and the Secretary of Agriculture). 
does not have to join all the protocols, just a minimum of one. It is not desirable to have a process where states would join the master treaty, not have any obligations under a protocol, but have the power to cause difficulties for other nation states. Agreeing to be part of a protocol will require some level of national implementation, depending on the topic. ${ }^{114}$

As treaties can create stand-alone organizations, something must be said about the internal operation of a treaty. One key issue is whether or not to have an administrative staff organization that exists permanently, not just during the meetings of the Parties. ${ }^{115}$ Today, most global treaties have a Secretariat to carry out much of the communication and program development for the treaty regime. ${ }^{116}$ These provisions are set out in Articles 14 through 25.117 These provisions are within the norm of existing treaties and follow some of the provisions of CITES. ${ }^{118}$ These articles also contain a number of procedural points for the operation of the treaty that will not be described in this Article, but should not be controversial.

Articles 26 through 31 contain the provisions necessary to bring the treaty into legal existence. ${ }^{119}$ To be bound by the provisions of a treaty or a protocol, a country must ratify or accept the treaty using whatever internal process it has adopted. ${ }^{120}$ Then it gives notification to the world of its acceptance of obligations by depositing a formal document with the depository government. ${ }^{121}$ The government that will

114 ICPA, supra n. 103, at arts. 14-25.

115 See generally e.g. Lisa Tabassi, The Convention on the Prohibition of the Development, Production, Stockpiling and Use of Chemical Weapons and on Their Destruction, in Making Treaties Work 273, 274 (Geir Ulfstein ed., Cambridge U. Press 2007) (explaining how the Chemical Weapons Convention created a intergovernmental treatyimplementing body, the Organization for the Prohibition of Chemical Weapons).

116 Hunter et al., supra n. 86, at 250 ("Secretariats are the information clearinghouses for most conventions.").

117 ICPA, supra n. 103, at arts. 14-25 (referencing: Art. 14: The Secretariat; Art. 15: Standing Committee; Art. 16: Conference of the Parties; Art. 17: Participation by Other than Contracting States; Art. 18: Rules of Procedure and Financial Rules; Art. 19: Periodic Reports; Art. 20: Amendment of the Convention or a Protocol; Art. 21: Annexes and Amendments to Annexes; Art. 22: Resolution of Disputes; Art. 23: Trade; Art. 24: Effect on Domestic Legislation and International Conventions; and Art. 25: Reservation).

118 CITES, supra n. 19, at art. XII ("Upon entry into force of the present Convention, a Secretariat shall be provided by the Executive Director of the United Nations Environment Programme. To the extent and in the manner he considers appropriate, he may be assisted by suitable inter-governmental or nongovernmental international or national agencies and bodies technically qualified in protection, conservation and management of wild fauna and flora.").

119 ICPA, supra n. 103, at arts. 26-31 (referencing: Art. 26: Signature; Art. 27: Ratification, Acceptance, Approval; Art. 28: Accession; Art. 29: Entry into Force; Art. 30: Denunciation; Art. 31: Depositary).

120 See generally Anthony Aust, Handbook of International Law 74 (2d ed., Cambridge U. Press 2010) (noting that a country must ratify the treaty and make it a part of the domestic law of that country).

121 Vienna Convention, supra n. 10, at art. 77(1)(c) (the international protocol for a depository). 
perform that task is subject to negotiations and is not stated in this draft. Also, the remaining issue to be negotiated is how many nation states must agree to acceptance, and thus ratification, of the treaty before it becomes international law. Article 29 suggests ten nation states as the threshold of becoming an effective treaty. ${ }^{122}$

There are four suggested protocols that accompany the Treaty:

Companion Animal Protocol

Protocol for the Care of Exhibited Wildlife

Protocol for the Taking of Wild Animals

Protocol for the International Transportation of Animals

These are included in the Appendix, but there is not enough space here to consider all of them in detail. If formal negotiations were to begin, these may or may not be part of the initial treaty. That would be up to the nation states in the negotiation. They are all structured the same. The Companion Animal Protocol is used as a sample.

As with the umbrella ICPA, there are initial operating principles and definitions that give focus for provisions of a particular protocol only. In the context of the animal welfare issues being discussed in the U.S. today, the topics, scope, and restrictions of the proposed protocol will seem modest. And while to those active in animal welfare issues, U.S. law often seems inadequate, ${ }^{123}$ the U.S. is ahead of the law and public policy discussion of most of the world. An exception is the EU, which may well be ahead of the U.S. in a number of areas. ${ }^{124}$ To draw in a majority of countries around the globe, the provisions of an international treaty must represent modest steps forward. They must help solve issues that exist within other countries. For example, pets are often seen as family members within the U.S. This view, however, is not shared throughout the world. ${ }^{125}$ While in the U.S. the issues around veterinary malpractice and how to measure damages for harm

122 ICPA, supra n. 103, at art. 29 ("Entry into Force: 1 . The present Convention shall enter into force ninety days after the date of deposit of the tenth instrument of ratification, acceptance, approval, or accession, with the Depositary Government.").

123 See generally Stephanie J. Engelsman, World Leader-At What Price? A Look at Lagging American Animal Protection Laws, 22 Pace Envtl. L. Rev. 329 (2005) (arguing that animal protection laws in the U.S. have failed to ensure that animals are free from unnecessary pain and suffering).

124 See generally e.g. Pedersen, supra n. 31, at 10 (noting that in the past ten years some of the major breakthroughs in animal welfare legislation within the EU include: an EU-wide law to eliminate battery cages; the extension of constitutional acknowledgement of animals in two European nations; and the establishment of an EU-wide conference on animal welfare).

125 Elizabeth Paek, Fido Seeks Full Membership in the Family: Dismantling the Property Classification of Companion Animals by Statute, 25 U. Haw. L. Rev. 481, 482 (2003) (identifying the increasing perception of pets in the U.S. as members of the family); but see Alissa Wolf, The World Pet Market Booms, http://petshops.about.com/od/PetStore Operations/a/World-Pet-Market-Trends.htm (2011) (accessed Apr. 8, 2012) (discussing that even the U.S. and U.K. have been the leaders in the world pet market, "a number of other countries are emerging as global pet forces with which to be reckoned" and specifically discussing pet ownership in China, India, Brazil, Mexico, and Latin America). 
to a pet are of major importance, ${ }^{126}$ in most of the developing world the mere establishment of a veterinary service available for pet animals would be a significant step forward.127 Any suggestion that pets should not be property is a non-starter from a global perspective. ${ }^{128}$ And because a key goal of the treaty is to build an international community with a focus on animal issues, the provisions of the treaty and its protocols can only be as progressive on animal welfare issues as is politically feasible at a particular point in time. The idea of an ongoing community is to allow the politically acceptable consensus to grow more protective over time.

As might be expected within the Companion Animal Protocol, the first articles imposing obligations on the states seek to create the positive duties of pet ownership and to prohibit the negative effect of cruelty. ${ }^{129}$ This Article uses a tool that is important to the structure of the various protocols, an annex to the protocol. Treaties by their nature are short. ${ }^{130}$ Additionally, once a treaty or a protocol is adopted, it is extremely hard to amend. ${ }^{131}$ Therefore, there needs to be a mechanism to allow some levels of change as time goes by without changing the general nature of the treaty. Thus, Article 4 has four topics of prohibitions: cruel acts, nature of restraints, training, and physical use (overburdening). ${ }^{132}$ If these categories are considered in regard to all the possible species that are pets around the world, the Article would turn into an encyclopedia. Instead, the Article says that the details about a particular species can be set out in Annex A to this protocol. During the initial negotiations, it is expected that some particulars will populate this Annex, but the key is that over time the Parties to this Protocol can modify and add to the Annex at conferences of the parties

126 Christopher Green, The Future of Veterinary Malpractice Liability in the Care of Companion Animals, 10 Animal L. 163, 166-67 (2004).

127 See generally e.g. The Intl. Fund for Agric. Dev., Livestock Health, http://www. ifad.org/lrkm/theme/health/health.htm (accessed Apr. 8, 2012) (identifying the difficulties of establishing veterinary services in developing countries).

128 See David Hambrick, A Legal Argument Against Animals as Property, in People, Property, or Pets? 55, 55 (Marc D. Hauser et al. eds., Purdue U. Press 2006) (stating that countries with "animal welfare laws" continue to treat animals as property); Bruce A. Wagman \& Matthew Liebman, A Worldview of Animal Law 26 (Carolina Academic Press 2011) (stating that animals have been classified as property in every legal system where the status of animals have been directly addressed, and that even if it has not been directly addressed, "the treatment of animals under the law of every country results in de facto status as property").

129 Companion Animal Protocol art. 7, cl. 4 (unadopted, proposed April 4, 1988), http:/ /animallaw.info/treaties/itconfprotanimal.htm (accessed Apr. 8, 2012) (creating specific duties for the care and attention of an animal as well as prohibiting specific acts of cruelty).

130 Contra Aust, Modern Treaty Law and Practice, supra n. 13, at 427-38 (discussing how treaties are becoming longer and more complex).

131 See id. at 262 (stating that "amending a multilateral treaty can raise a multitude of problems").

132 Companion Animal Protocol, supra n. 129, at art. 4, cl. 3. 
without having to go through the full protocol amendment process. ${ }^{133}$ This allows for incremental change over time. ${ }^{134}$

Article 5 deals with the issue of inappropriate species to keep as pets. ${ }^{135}$ It is presumed that a fair consensus can be obtained to prohibit most endangered or dangerous species as pets: lions, tigers, chimpanzees, wolves, bears, and venomous snakes. But, again, an annex is used as the listing mechanism so it can be added to over time.

Article 9 might be considered radical in the context of the U.S. because the cutting off of animal parts to have pets conform to "standards" is an accepted practice by many. ${ }^{136}$ Article 9 states:

1. Surgical operations for the purpose of modifying the appearance of a companion animal or for other non-curative purposes shall be prohibited and, in particular:

(a) the docking of tails;

(b) the cropping of ears;

(c) devocalizsation; and

(d) declawing and defanging. ${ }^{137}$

Other operations or procedures, which the Contracting Parties believe inappropriate, may be listed as an Annex to the Protocol (unless necessary for the wellbeing of the particular pet).

While these prohibitions might be acceptable to Parties within the category of pets, the cutting off of body parts for commercial animals (e.g., sheep tail docking) is a much more difficult issue as it goes to perceived economic interests, thus making it much more difficult to initially address.

Article 13 requires each nation state to domestically implement the provisions of the treaty. ${ }^{138}$ A treaty does not create law binding on the individuals within a nation state, but only on the nation state itself. ${ }^{139}$ The passage of domestic law is expected after the ratification of

133 See also CITES, supra n. 19, at art. XV, cl. 1(b), 2(d) (It takes a two-thirds vote of Party States to adopt a change; if a particular country is really unhappy with the change, that country can take a reservation on that one listing within 60 days after the meeting.); see generally The Evolution of CITES ch. 5 (7th ed., CITES Secretariat 2003) (This is the structure of CITES for the listing of endangered species. The initial negotiated treaty language had a number of species set out in Appendix I and Appendix II, but at each Conference of the Parties held since inception, there has been significant focus of energy on the issues of additions, deletions, and modifications of the species listed on the Appendixes.).

134 ICPA, supra n. 103, at art. 21.

135 Id. at art. 5.

136 Wagman \& Liebman, supra n. 128, at 103; see e.g. Am. Kennel Club, Canine Legislation Position Statement, http://www.akc.org/pdfs/canine_legislation/position_statements/Ear_Cropping_Tail_Docking_and_Dewclaw_Removal.pdf (updated 2012) (accessed Apr. 8, 2012) (stating that the American Kennel Club recognizes that ear cropping, tail docking, and dew claw removal "as described in certain breed standards, are acceptable practices integral to defining and preserving breed character").

137 Companion Animal Protocol, supra n. 129, at art. 9.

138 Id. at art. 13, cl. 1.

139 Aust, Modern Treaty Law and Practice, supra n. 13, at 178 ("[I]nternational law is concerned with the rights and obligations of states."). 
the treaty by a nation state. ${ }^{140}$ Admittedly, the present draft does not set a deadline for adoption of the domestic law, and such a deadline (within two years, perhaps) would be helpful.

As with all international agreements, the key issue is enforcement of the provisions of the treaty. ${ }^{141}$ Regrettably, many international agreements lack a compelling process to make countries comply with their obligations. ${ }^{142}$

There is no international police force that can compel compliance with treaty obligations. ${ }^{143}$ Again, the concept of sovereignty limits the willingness of countries to sign treaties subjecting themselves to the will of others. Therefore, the implementation provisions of the protocols are modest and, perhaps, politically acceptable. Article 15 (2) states: "Each Contracting Party may prohibit companion animal trade with any State which refuses to comply with the provisions of this Protocol and its Annexes."144 This at least allows unilateral enforcement efforts by nation states with the political will to confront other nation states, whether or not a party to the treaty. If utilized, this provision would also be an incentive to join the treaty since a nation state would have to comply with the limitations of the treaty even if it is not a member.

\section{PROSPECTS FOR ADOPTION OF A TREATY}

Private parties and non-profit organizations do not have the capacity to call for a treaty negotiations process; a nation state must take up that task. ${ }^{145}$ As the existence of the language in the Appendix proves, writing possible treaty language is the easy part. The difficulty is in finding a country willing to initiate the process. For a country to do so requires a level of political concern within the nation state, such that the expenditure of human and financial resources is justified. This initial hurdle has not yet been overcome, but it is possible a country can be found that is willing to take a leadership role. There is no expectation that it would be the U.S. It should be understood that there are any number of politically powerful voices within the U.S.

$140 I d$. at 179 (stating that new legislation may be needed to implement a treaty in domestic law).

141 See Geir Ulfstein et al., Introduction, in Making Treaties Work: Human Rights, Environment, and Arms Control 4 (Geir Ulfstein et al. eds., Cambridge U. Press 2007); see generally Jack L. Goldsmith \& Eric A. Posner, The Limits of International Law (Oxford U. Press 2005) (entire work discussing the limits international law and specifically focusing on compliance).

142 See generally Goldsmith \& Posner, supra n. 141 (entire work discussing that international law cannot pull countries into compliance against their national interests).

143 Hunter et al., supra n. 86, at 363 (noting that enforcement of international law is different than enforcement in a national system because, "no international police, prosecutors, or courts have the independent authority to monitor and adjudicate compliance and respond to instances of non-compliance").

144 Companion Animal Protocol, supra n. 129, at art. 15.

145 Vera Gowlland-Debbas, Introductory Remarks, in Multilateral Treaty-Making 5 (Vera Gowlland-Debbas ed., Kluwer L. Intl. 2000). 
who would not want a treaty that might interfere with the existing commercial use of animals. The lobbying by these groups would be a simple message to elected officials: "Don't go there, just leave the issue alone, the status quo is what we are paying you to keep."

Historically there have been two sources of treaty initiation outside of nation states themselves. A division of the United Nations might initiate a process that the nation states become a part of, or large international non-government organizations could lobby governments to take up the issue. ${ }^{146}$ Nongovernmental organizations might be willing to do the initial drafting, spend the money for holding a hearing and discussion meeting, and invite government participation. ${ }^{147}$ The hope would be that a sufficient level of interest could be generated such that one or a group of governments would take a leadership position and call for formal nation state-to-nation state negotiations.

It is also possible, and perhaps a prerequisite to action, that economic users of animals, faced with a great diversity of animal welfare standards around the globe, will decide to support a treaty in order to obtain uniform global standards. Some corporations might well have the policy position that "we would enhance animal welfare for the animals under our care, if our economic competition would be required to meet the same standards." Therefore a global treaty with protective animal welfare standards would raise the economic playing field to a more comfortable, ethical level.

But if we assume that one country can start the process, then the decision of other states to join the negotiations is slightly different. Other countries would come to the negotiations out of self-interest. They would not want a global treaty to proceed without being a part of the process, allowing them to help shape the provisions of the treaty and protect or assert their self-interests. There would be a fear of a change of the welfare rules that would put them at a disadvantage. Now this shows the second pressure point. The call for negotiations should not occur unless there is some level of belief that the results of the negotiations will not simply make present animal welfare treatment the global standard.

The risk is that present commercial users of animals would capture the process through government representatives and establish

146 Jose E. Alvarez, The New Treaty Makers, 25 B.C. Intl. Comp. L. Rev. 213, 217-18 (2002); see generally Louise Doswalk-Beck, Participation of Non-Governmental Entities in Treaty-Making: The Case of Conventional Weapons, in Multilateral Treaty-Making, supra n. 145, at 41 (Vera Gowlland-Debbas ed., Kluwer L. Intl. 2000) (discussing the two main stages of participation of nongovernmental entities).

147 This appears to be the path that WSPA has taken with the Animal Welfare Declaration. Wagman \& Liebman, supra n. 128, at 25 (The Universal Animal Welfare Declaration (UAWD) is sponsored by the WSPA, which, since 2000, has sought to gain the agreement of multiple countries with the eventual goal of gaining ratification by the UN. As of 2011, over thirty countries were considering the UAWD for formal presentation.). 
such a low bar of welfare for animals that there would be no enhancement over existing negative conditions. Indeed the risk is that the treaty could be transformed into something enhancing the economic, and therefore political, power of the global and national corporations that control so many millions of animals. Considerable judgments must be made about when and under what conditions negotiations of a treaty might reduce or control the risk of a loss for the animals.

If a treaty were negotiated, would the U.S. adopt it? This is doubtful. The U.S. Senate has chosen a path of non-participation with any number of important international agreements over the past several decades. ${ }^{148}$ There is political gridlock and an arrogance that the U.S. is so powerful by itself that it does not have to compromise and join other states.

At present, the largest hindrance to the consideration and adoption of an animal welfare treaty is the negative condition of much of the global economy. Animal issues cannot rise to a level of international concern unless the economics of the world recover, allowing the middle class of most countries to become comfortable and political issues other than economic survival to become important again. If a country is not taking care of the economic needs of its citizens (which include education and health care), then there is very little political space for the welfare of animals. At the moment, the stars are not aligned for the adoption of an animal welfare treaty. There is hope, however, that the alignment might occur in the future; those interested in animal welfare issues must be ready to take advantage of a political opening whenever it might occur.

148 See Inst. for Agric. \& Trade Policy, The Treaty Database: A Monitor of U.S. Participation in Global Treaties, http://www.unausa.org/Document.Doc?id=147 (Dec. 2004) (accessed Apr. 8, 2012) (discussing the U.S.'s steady decline in support for UN treaties and specifically finding that out of 549 reviewed treaties, the US only ratified 158, which is fewer then one out of every three treaties). 


\title{
VI. INTERNATIONAL CONVENTION FOR THE PROTECTION OF ANIMALS
}

\author{
Preamble
}

\section{THE CONTRACTING PARTIES,}

REALIZING the need to establish effective and comprehensive international standards for the treatment of animals, and

RECOGNIZING that humans derive many diverse benefits from their associations with animals and their utilization of them, and

RECOGNIZING that the misuse and wastage of animals impairs the conservation of the environment as well as cultural and economic development, and

RECOGNIZING the widespread international concern over the many and varied abuses of animals which constitute cruelty, and

RECOGNIZING that heretofore there existed no comprehensive international agreement which effectively confronted these abuses so as to eliminate or to mitigate their severity, and

SEEKING to institute a practical mechanism which resolves the differences arising from the character and implementation of animal protective legislation of the various States, and

CONVINCED that meaningful and effective improvements in the treatment of animals and fulfillment of mankind's obligations toward animals and natural systems can be assured through cooperative action by all States,

HAVE AGREED upon the following provisions:

\section{ARTICLE 1: Fundamental Principles}

1. Humans and animals co-exist within an interdependent ecosystem. Humans and animals share an evolutionary heritage. Humans, as moral beings, have an obligation to act responsibly toward animals.

2. Life has intrinsic value. No animal should be killed unnecessarily or be subjected to cruel acts or to unnecessary suffering.

3. When humans have control over specific animals they have a positive obligation to provide these animals with an environment and care appropriate for the species.

\section{ARTICLE 2: Definitions}

A particular animal shall be categorized by both its species and the specific environment in which that animal is found. For the purposes of this Convention and its Protocols, unless the context requires otherwise, or the term in question is otherwise defined within a specific Protocol, then the term:

a. "animal" means any nonhuman mammal, bird, reptile, amphibian or fish and any other organisms which may be included specifically within a particular protocol.

b. "wildlife" includes any animal of a species which has evolved as a part of the local ecosystem in which it is found or is a species which has escaped human control and establishes a self-sustaining reproducing population within a particular habitat, or is of a species which has adapted to co-existence with humans within the urban environment. 
c. "captive wildlife" includes any animal of a wildlife category which comes under the control of humans and any animal from subsequent generations which are born from such animal.

d. "domestic animals" refer to species which, within the context of the local culture, have traditionally been under the physical control, bred by and used by humans.

e. "companion animals" mean animals of which humans have possession and control of for a primary use other than economic benefit.

f. "commercial animals" shall refer to animals under the control of humans for the primary purpose of economic gain or production of goods or services. This includes, but is not limited to, farm and ranch animals, working animals, laboratory animals, and animals used by humans in sport or entertainment.

\section{ARTICLE 3: The Capturing or Killing of Wildlife}

The Contracting Parties shall take all appropriate steps to minimize and control the capture or killing of wildlife, particularly the methods thereof, in order to reduce the suffering of target animals to the minimum possible, and to minimize to the greatest extent possible indiscriminate harm to nontarget animals or the environment.

\section{ARTICLE 4: Wildlife Management and Habitat}

The Contracting Parties shall take all appropriate steps to use those scientific management practices which result in the least suffering to wildlife and shall conserve wildlife habitat wherever possible.

\section{ARTICLE 5: Captive Wildlife Care}

The Contracting Parties shall take all appropriate steps to assure that humans having custody of captive wildlife provide an appropriate environment and the necessary care for the wellbeing of the animals and that captive wildlife not be subjected to unnecessary suffering or cruelty.

\section{ARTICLE 6: Transportation of Animal}

The Contracting Parties shall take all appropriate steps to prevent cruelty and reduce suffering to the minimum in the transportation of any animal.

\section{ARTICLE 7: Companion Animals}

The Contracting Parties shall take all appropriate steps to protect companion animals from cruelty, to assure that humans provide them with responsible care and to prevent inappropriate species from being used as companion animals.

\section{ARTICLE 8: Commercial Animals}

The Contracting Parties shall take all appropriate steps to assure that commercial animals shall be provided an appropriate environment and the necessary care for their wellbeing and shall be reared, maintained, used, and killed without the infliction of unnecessary suffering or cruelty. 
ARTICLE 9: Animals Used in Scientific Research

The Contracting Parties shall take all appropriate steps to minimize the use of animals in scientific research, testing, and education, and to prevent cruelty and reduce suffering to the minimum in those animals which are used.

\section{ARTICLE 10: General Undertakings}

1. The Contracting Parties shall individually and jointly take all appropriate measures, in accordance with the provisions of this Convention and those protocols in force to which they are party, to prevent the subjection of animals to cruelty and unnecessary suffering and to conserve the natural habitat of wildlife.

2. The Contracting Parties shall cooperate in the formulation and adoption of additional protocols as the opportunities arise.

3. The Contracting Parties undertake as far as possible to cooperate directly, or, when appropriate, through competent regional or international organizations in all appropriate fields including, but not restricted to science, education, law, and technology, and to exchange data as well as other information for the purpose of this Convention.

4. The Contracting Parties shall cooperate in the implementation of this Convention and the enforcement of its provisions.

5. The official working languages of this Convention shall be English, French, and Spanish. The Contracting Parties shall make every effort in communications with the Secretariat and other Contracting Parties to use one of these three languages.

ARTICLE 11: Relationship Between the Convention and Protocols

1. No State may become a Contracting Party to this Convention unless it becomes a Contracting Party to at least one of the protocols at the same time. No State may become a Contracting Party to a protocol unless it is, or becomes, a Contracting Party to this Convention at the same time.

2. Any protocol to this Convention shall be binding only on the Contracting Parties to the protocol in question.

3. Decisions concerning any protocol pursuant to Articles 16, 20 and 21 of this Convention shall be taken only by the Contracting Parties to the protocol concerned.

\section{ARTICLE 12: Adoption of Additional Protocols}

1. The Contracting Parties and other invited States, at a plenipotentiary conference, may adopt additional protocols to this Convention. The conference shall be convened at the request of at least ten States.

2. Pending the entry into force of this Convention the Secretariat may, after consulting with the signatories to this Convention and other States, seek the convening of a plenipotentiary conference for the purpose of adopting additional protocols.

ARTICLE 13: Designation of Responsible Authority

1. Each Contracting Party shall designate an individual, office or organization to be responsible in matters concerning the Convention. This individual, office or organization shall be the responsible agency for all official communication between the Secretariat and the Contracting Party. 
2. It shall be permissible for any Contracting Party to further designate different individuals, offices, or organizations for each Protocol which is in force for the Contracting Party in question.

\section{ARTICLE 14: The Secretariat}

1. Upon entry into force of the present Convention, an interim Secretariat shall be provided by the Contracting Parties. To the extent and in the manner the Interim Secretariat considers appropriate, the Interim Secretariat may be assisted by suitable governmental, intergovernmental, or nongovernmental international or national agencies and organizations qualified in the care of animals. The interim Secretariat shall call a meeting of the Conference of the Contracting Parties not later than one year after the entry into force of the present Convention.

2. The Conference of the Contracting Parties to this Convention shall appoint a permanent Secretariat to administer the day-to-day functioning of the present Convention and to perform any special duties entrusted to it. The composition of the Secretariat, its headquarters, and other matters which relate to this functioning shall be determined by the Conference of the Parties.

3. The permanent Secretariat shall have the following duties and authority:

a. to convene and prepare the meetings and Conferences of Contracting Parties;

b. to transmit to the Contracting Parties notifications, reports, and other information received in accordance with subsequent Articles;

c. to respond to inquiries by, and information from, the Contracting Parties, and to consult with them on questions relating to this Convention and the protocols and annexes thereto;

d. to ensure the necessary coordination with other international bodies which the Contracting Parties consider competent and, in particular, to enter into such administrative arrangements as may be required for the effective discharge of the Secretariat functions;

e. to make recommendations to the Contracting Parties for the implementation of the Convention and adopted protocols;

f. to consider problems of implementation of the Convention or a Protocol, to make recommendations to a Contracting Party for the correction of any outstanding problems and when appropriate to make a report along with recommendations to the Contracting Parties at the next Convention of the Contracting Parties;

g. to undertake studies that will contribute to the implementation of this Convention;

h. to seek funding, as required, from governmental and nongovernmental sources;

i. to receive reports from non-government groups concerning issues which arise under the provision of this Convention;

j. to work with the Standing Committee as appropriate;

k. to report biennially to the Conference of the Parties;

l. to perform the functions assigned to it by the protocols to this Convention;

m. to perform such other functions as may be assigned to it by the Contracting Parties. 


\section{ARTICLE 15: Standing Committee}

1. At the first conference of the Contracting Parties a Standing Committee consisting of 7 Contracting Parties shall be elected. Subsequent elections shall be held at each regular Conference of the Contracting Parties.

2. Membership on the Standing Committee shall rotate between the Contracting Parties and shall take into account the needs of geographic representation. If not an elected member, the depository government shall have the right to attend and participate as a non-voting member.

3. The Standing Committee shall adopt its own rules of operation.

4. In order to discharge its functions, the Standing Committee may, on its own initiative, arrange for meetings of groups of experts.

5. The Standing Committee shall meet at least once between the Conferences of the Parties.

6. The Standing Committee may consider problems of implementation of the Convention and Protocols. The results of any such investigation shall be forwarded to all the Contracting Parties, along with recommendations. 7. The Standing Committee may also draft new protocols or amendments to the Convention, existing protocols, or annexes of a protocol. Any such proposal shall be distributed by the Secretariat to the Contracting Parties for consideration in accordance with Article 12, 20, or 21.

8. The Standing Committee shall have the obligation to provide administrative and financial oversight of the operation of the Secretariat's office as directed by the resolutions of the Conference of the Parties.

\section{ARTICLE 16: Conference of the Parties}

1. After the initial Conference, convened in accordance with Article 14, regular meetings of the Conference shall be called every two years. Extraordinary meetings of the Conference of the Contracting Parties shall be called by the Secretariat on receipt of a written request of at least one-third of all Parties to the Convention.

2. Only Contracting Parties may vote at a Conference. Any Contracting Party may be represented by one or more delegate. Each delegation shall have one vote. Within the areas of its competence, the European Economic Community, if a Contracting Party, may exercise its right to vote with a number of votes equal to the number of its member States which are Contracting Parties to this Convention; the European Economic Community shall not exercise its right to vote in cases where the member States concerned exercise theirs, and conversely.

3. A majority of the Contracting Parties shall constitute a quorum for purposes of holding a Conference. Except as provided in Articles 20 and 21, and Section 5 of this Article, all votes shall be decided on the basis of a simple majority of those present and voting. When an issue is solely within the provisions of one of the protocols then only those Contracting Parties to the protocol may vote.

4. The Conference shall review the effectiveness of the Convention and of existing protocols, review and adopt budgets for the Secretariat, consider the recommendations of the Secretariat or Standing Committee, and transact such other business as it considers necessary to implement the provisions of this Convention and its protocols.

5. Upon motion and a two-thirds vote of those present and voting at any Conference of the Contracting Parties, a Contracting Party may be sanc- 


\begin{tabular}{lllll}
\hline$\backslash$ jciprod01\productn $\backslash L \backslash L C A \backslash 18-2 \backslash$ lca204.txt & unknown & Seq: 34 & 6-AUG-12 & 11:45 \\
\hline
\end{tabular}

tioned when it is deemed to have violated an obligation under the Convention or a Protocol to which it is a party.

ARTICLE 17: Participation by Other than Contracting States

1. Upon a vote of the Contracting Parties any State, international agency, or body may be invited as an observer to a Conference of the Parties or meeting of the Standing Committee.

2. Any body or agency qualified in protection, conservation, or humane care of animals, or otherwise involved with the use of animals, in the following categories, which has informed the Secretariat at least thirty days in advance of its desire to be represented at meetings of the Conference by observers, shall be admitted unless at least one-half of the Parties present object:

a. international agencies or bodies, either governmental or nongovernmental;

b. national governmental agencies and bodies; and

c. national nongovernmental agencies or bodies.

Once admitted, these observers shall have the right to participate but not to vote.

3. In the case of any Committee meetings held between Conferences, any organization which was represented at the immediately preceding Conference shall be allowed observer status at a Committee meeting, except when the Committee excludes all observers by majority vote.

\section{ARTICLE 18: Rules of Procedure and Financial Rules}

1. The Contracting Parties shall adopt rules of procedure for their meetings and conferences provided for in Articles 15 and 16 above.

2. The Contracting Parties shall adopt financial provisions, prepared in consultation with the Secretariat, to determine, the level of each Contracting Party's financial participation.

\section{ARTICLE 19: Periodic Reports}

1. Upon joining this Convention, each Contracting Party shall provide the Secretariat with copies of all domestic law, translated into an official language of the Convention, which pertains to its obligations under the Convention or any of the protocols to which it is a Contracting Party. If a Contracting Party shall subsequently become a party to an additional Protocol then copies of relevant domestic law shall be forwarded to the Secretariat. Any subsequent changes or additions in relevant domestic law shall be forwarded to Secretariat when adopted.

2. Contracting Parties shall provide biennial reports to the Secretariat which explain its efforts to implement the obligations of this Convention. These reports shall be submitted upon entry into force of the Convention for the Contracting Party in questions and thereafter six months prior to each regular Conference meeting. Additional reporting responsibility may arise under specific protocols.

3. Biennial reports shall be compiled by the Secretariat as appropriate and made available to all Contracting Parties and other interested individuals and organizations. 
ARTICLE 20: Amendment of the Convention or a Protocol

1. Any Contracting Party to this Convention may propose amendments to the Convention. Amendments shall be adopted by an extraordinary conference which shall be convened by the Secretariat at the request of twothirds of the Contracting Parties.

2. Any Contracting Party to this Convention may propose amendments to any protocol to which it is a member. Such amendments shall be adopted by an extraordinary conference which shall be convened by the Secretariat at the request of two-thirds of the Contracting Parties to the protocol concerned.

3. Amendments to this Convention shall be adopted by a three-fourths majority vote of the Contracting Parties to the Convention which are present and voting either affirmative or negative at the extraordinary conference, and shall be submitted by the Depositary for acceptance by all Contracting Parties to the Convention. Amendments to any protocol shall be adopted by a three-fourths majority vote of the Contracting Parties to such protocol which are present and voting either affirmative or negative at the extraordinary conference, and shall be submitted by the Depositary for acceptance by all Contracting Parties to such protocol.

4. Acceptance of amendments shall be notified to the Depositary in writing. Amendments adopted in accordance with paragraph 3 of this Article shall enter into force between Contracting Parties having accepted such amendments on the thirtieth day following the receipt by the Depositary of notification of their acceptance by at least two-thirds of the Contracting Parties to this Convention or to the protocol concerned, as the case may be. For Contracting Parties subsequently accepting the amendment, the amendment shall be effective thirty days after receipt of the notification of acceptance.

5. After the entry into force of an amendment to this Convention or to a protocol, any new Contracting Party to this Convention or such protocol shall become a Contracting Party to the instrument as amended.

6. If a technical mistake of translation is discovered in any text after the adoption of the Convention, a protocol, or amendment to either, the Secretariat shall so report to the Contracting Parties in writing. The necessary change will be made by the Secretary sixty days after notification unless controversy exists, in such case the problem will be reported at the next Conference of the Parties.

\section{ARTICLE 21: Annexes and Amendments to Annexes}

1. Annexes to any protocol shall be considered an integral part of such protocol.

2. Except as may be otherwise provided in any protocol, the following procedure shall apply to the adoption and entry into force of any annex or amendments to annexes to any protocol:

a. any Contracting Party to a protocol may propose an annex or an amendment to an annex of that protocol at a meeting referred to in Article 16;

b. such annex or amendments shall be adopted by a three-fourths majority vote of the Contracting Parties to such protocol as the annex may be a part; 


\begin{tabular}{lllll}
\hline$\backslash$ jciprod01\productn $\backslash L \backslash L C A \backslash 18-2 \backslash$ lca204.txt & unknown & Seq: 36 & 6 -AUG-12 & $11: 45$ \\
\hline
\end{tabular}

c. the Secretariat shall, without delay, communicate the new annex or amendments so adopted to all Contracting Parties;

d. any Contracting Party that is unwilling to accept an annex or amendment to an annex shall so notify the Depositary in writing within sixty days;

e. the Depositary shall without delay notify all Contracting Parties of any notification received pursuant to the preceding sub-paragraph;

f. on expiration of the sixty-day period referred to in sub-paragraph $d$ above, the annex or amendment to an annex shall become effective for all Contracting Parties to the protocol concerned which have not submitted a notification in accordance with the provisions of sub-paragraph $d$.

3. The adoption and entry into force of a new annex to any protocol shall be subject to the procedure of the previous paragraph, provided that, if any amendment to the protocol is involved, the new annex shall not enter into force until such time as the amendment to the protocol concerned enters into force.

4. All proposals and supporting reports by Contracting Parties for new annexes or to amend any annex must be submitted to the Secretariat at least ninety days before the scheduled regular or extraordinary meeting of the Conference of the Parties at which the proposal is to be submitted for debate and vote, and distributed by the Secretariat to all Contracting Parties at least sixty days before any such meeting.

5. No proposal for a new annex or to amend an annex shall be voted upon at a meeting of the Conference of the Contracting Parties unless it is supported by a report, distributed in accordance with the provisions of Paragraph 4 of this Article, and containing sufficiently pertinent detail to permit the proposal to be thoroughly argued in open debate. The format for any such report may be adopted by resolution of the Parties.

\section{ARTICLE 22: Resolution of Disputes}

Disputes between two or more Contracting Parties concerning the interpretation or implementation of the present Convention shall be subject to negotiation between the Contracting Parties involved in the dispute. If negotiation fails, Contracting Parties may, by mutual consent, submit the dispute to arbitration, in particular that of the Permanent Court of Arbitration at The Hague. The Contracting Parties submitting the dispute shall be bound by the arbitral decision.

\section{ARTICLE 23: Trade}

1. In order to support worldwide participation in the Convention, Contracting Parties are encouraged to avoid trade in any animal or animal parts and derivatives with those States that are not participants in this Convention. If trade with non-participants is allowed, then certification by the non-participant State of compliance with Convention provisions and standards for the animals being traded are a precondition to trade.

2. In order to encourage the full implementation of this Convention, Contracting Parties are encouraged to restrict the importation of any animal or animal parts or derivatives from those Contracting Parties that keep or manage such animals in a manner inconsistent with any of the provisions of this Convention and its protocols. 


\section{ARTICLE 24: Effect on Domestic Legislation and International Conventions}

1. The provisions of the present Convention shall in no way affect the right of Contracting Parties to adopt stricter domestic measures regarding the treatment or transport of live animals, or regarding practices to be followed in the capturing or killing of animals, or other humane care requirements for any animal.

2 . The provisions of the present Convention shall in no way affect the provisions of any domestic measures or the obligations of Contracting Parties deriving from any treaty, convention, or international agreement relating to the trade, taking, possession, treatment, or transport of animals which is in force for any Contracting Party when they become a Contracting Party.

\section{ARTICLE 25: Reservation}

1. The provisions of the present Convention or Protocols shall not be subject to general reservations. Specific reservations may be entered in accordance with the provisions of this Article.

2. Any Contracting Party may, on depositing its instrument of ratification, acceptance, approval or accession, or within sixty days after the adoption of a new annex or an amendment to any annex as provided in Article 21, enter a specific reservation with regard to:

a. a specific species, subspecies or any other taxon specifically listed;

b. any specific technique or device prohibited or controlled;

c. any species-specific conditions of handling, housing, transportation, or use of animals.

3. Until a Contracting Party withdraws its reservation entered under the provisions of this Article, it shall be treated as a State not a Party to the present Convention with respect to trade in and treatment of the particular species or, as appropriate, parts or derivatives specified in such reservation.

\section{ARTICLE 26: Signature}

1. The present Convention shall be available for signature by all States and the European Economic Community.

2 . The present Convention shall be open for signature at until and thereafter at until

\section{ARTICLE 27: Ratification, Acceptance, Approval}

The present Convention shall be subject to ratification, acceptance, or approval. Instruments of ratification, acceptance, or approval shall be deposited with the Government of which shall be the Depositary Government.

ARTICLE 28: Accession

The present Convention shall be open indefinitely for accession. Instruments of accession shall be deposited with the Depositary Government.

\section{ARTICLE 29: Entry into Force}

1. The present Convention shall enter into force ninety days after the date of deposit of the tenth instrument of ratification, acceptance, approval, or accession, with the Depositary Government. 
2. For each State which ratifies, accepts or approves the present Convention or accedes thereto after the deposit of the tenth instrument of ratification, acceptance, approval, or accession, the present Convention shall enter into force 90 days after the deposit by such State of its instrument of ratification, acceptance, approval, or accession.

\section{ARTICLE 30: Denunciation}

Any Contracting Party may denounce the present Convention by written notification to the Depositary Government at any time. The denunciation shall take effect twelve months after the Depositary Government has received the notification.

\section{ARTICLE 31: Depositary}

1. The original of the present Convention, in the English, French, and Spanish languages, each version being equally authentic, shall be deposited with the Depositary Government which shall transmit certified copies thereof to all States that have signed it or deposited instruments of accession to it.

2. The Depositary Government shall inform all signatory and acceding States and the Secretariat of signatures, deposit of instruments of ratification, acceptance, approval, or accession, entry into force of the present Convention, amendments thereto, entry and withdrawal of reservations, and notifications of denunciation.

3. As soon as the present Convention enters into force, a certified copy thereof shall be transmitted by the Depositary Government to the Secretariat of the United Nations for registration and publication in accordance with Article 102 of the Charter of the United Nations.

In witness whereof the undersigned Plenipotentiaries, being duly authorized to that effect, have signed the present Convention. 


\title{
VII. COMPANION ANIMAL PROTOCOL
}

\author{
ARTICLE 1: Operating Principles
}

1. No person shall cause a companion animal unnecessary pain, suffering, or distress. No person shall abandon a companion animal.

2. Any person who is the keeper of a companion animal shall have the affirmative obligation to provide the companion animal with adequate food, water, shelter, and veterinary care.

3 . Wildlife, particularly captured wildlife, should not be utilized as companion animals.

\section{ARTICLE 2: Definitions}

1. A "keeper" is an individual who has possession of a companion animal, even though they may or may not be the owner of the companion animal. 2. A "stray animal" is a companion animal which is outside the bounds of its owner's or keeper's household and is not under the control or direct supervision of the owner or keeper.

3 . The "trading" of companion animals refers to a retail or wholesale business in substantial quantities, carried out for profit, and which involves the change of ownership of companion animals.

4. "Commercial breeding and boarding" is an operation mainly for profit which involves substantial quantities.

5. An "animal sanctuary" is a non-profit establishment or organization where companion animals may be kept in substantial numbers.

6. A "competent authority" is one designated by the Contracting Party to carry out the responsibilities of this Protocol.

7. The term "person" includes individuals, business entities, organizations, or agencies.

\section{ARTICLE 3: Ownership Limitation}

1. No companion animal shall be sold to individuals under the age of legal responsibility without the express consent of their parents or other persons exercising parental responsibilities to assume legal responsibility for the animal.

\section{ARTICLE 4: Care}

1. The keeper of a companion animal shall be responsible for the animal's health and welfare.

2 . The keeper of a companion animal shall provide the care and attention required by the species and breed of the animal, and in particular shall:

a. give it suitable and sufficient food and water;

b. provide it with adequate shelter from adverse environmental conditions;

c. provide it with adequate opportunities for exercise; and

d. take all reasonable measures to prevent escape.

3 . The keeper of a companion animal shall not:

a. subject the animal to cruel acts or conditions;

b. restrain an animal so as to preclude it from obtaining adequate food, water, and shelter; 


\begin{tabular}{lllll}
\hline$\backslash$ jciprod01 $\backslash$ productn $\backslash L \backslash L C A \backslash 18-2 \backslash$ lca204.txt & unknown & Seq: 40 & 6-AUG-12 & $11: 45$ \\
\hline
\end{tabular}

c. train an animal in a way which is detrimental to its health or cause unnecessary pain or suffering;

d. use an animal by forcing it to exceed its natural capacities or strengths.

4. Annex A to this Protocol shall contain species-specific requirements for the appropriate care and welfare of companion animals.

\section{ARTICLE 5: Inappropriate Companion Animals}

1. The offspring of animals already in the possession of humans are the preferred source of companion animals over captured wild animals.

2. No person shall be allowed to keep or own wildlife if any of the following conditions are present:

a. the animal is of an endangered species protected under domestic or international law;

b. the animal, as an adult, represents a physical danger to the keeper of the animal or others who might be expected to be in contact with the animal; or

c. the animal is unlikely to ever adjust to the confinement expected of a companion animal because of the sociological, physiological, or ecological needs of the animal.

3. Annex B to this Protocol shall contain a list of animals which the Contracting Parties determine are inappropriate for use as a companion animal.

4. It is inappropriate for any animal to be given away as a companion animal prize, award, or bonus.

\section{ARTICLE 6: Breeding}

The breeding or genetic manipulation of an animal is prohibited when it is foreseeable that either the health and welfare of a parent will be put to risk or that the offspring of any such process will have anatomical, physiological, or behavioral characteristics which result in increased risk of pain, injury, illness, or death of the offspring.

ARTICLE 7: Trading, Commercial Breeding and Boarding, Animal Sanctuaries

1. Any person who, at the time of the entry into force of this Protocol, is trading in or is commercially breeding or boarding companion animals, or is operating an animal sanctuary shall, within an appropriate period to be determined by each Contracting Party, declare this to the competent authority.

Any person who intends to engage in any of these activities shall declare this intention to the competent authority prior thereto.

2. This declaration shall stipulate:

a. the species of companion animals which are involved or to be involved;

b. the person responsible and his qualifications; and

c. a description of the premises and equipment used or to be used.

3 . The above-mentioned activities may be permitted by the competent authority only:

a. if the personal responsible has the competence and qualifications for the activity either as a result of professional training or of sufficient experience with companion animals; and 
b. if the premises and the equipment used for the activity comply with the requirements set out in Article 4.

4. The competent authority shall determine on the basis of declaration made under the provisions of Paragraph 1 and any other information available to it whether or not the conditions set out in Paragraph 3 are being complied with. If these conditions are not adequately met, it shall recommend measures and, if necessary for the welfare of the animals, it shall prohibit the commencement or continuation of the activity.

5. The competent authority shall, in accordance with national legislation, ensure compliance with the above-mentioned conditions.

ARTICLE 8: Advertising, Entertainment, Exhibitions, Competitions, and Similar Events

1. Companion animals shall not be used in advertising, entertainment, exhibitions, competitions, and similar events unless:

a. the organizer has created appropriate conditions for the companion animals to be treated in accordance with the requirements of Article 4; and

b. the companion animal's health and welfare are not put at risk.

2. No substances shall be given to, treatments applied to, or devices used on a companion animal for the purpose of increasing or decreasing its natural level of performance:

a. during competition; or

b. at any other time, when this would put at risk the health and welfare of the animal.

\section{ARTICLE 9: Surgical Operations}

1. Surgical operations for the purpose of modifying the appearance of a companion animal or for other non-curative purposes shall be prohibited and, in particular:

a. the docking of tails;

b. the cropping of ears;

c. devocalisation; and

d. declawing and defanging.

Other operations or procedures which the Contracting Parties believe inappropriate may be listed as an Annex to the Protocol.

2. Exceptions to these prohibitions shall be permitted only:

a. if a veterinarian considers non-curative procedures necessary for veterinary medical reasons or for the benefit of any particular animal; and b. to prevent reproduction.

3. a. Operations in which the animal will or is likely to experience severe pain shall be carried out under anesthesia only by a veterinarian or under his supervision.

b. Operations for which no anesthesia is required may be carried out by a person competent under national legislation.

\section{ARTICLE 10: Killing}

1. Only a veterinarian or another competent person shall kill a companion animal except in an emergency to terminate an animal's suffering when veterinary or other competent assistance cannot be quickly obtained or in any other emergency covered by national legislation. All killing shall be 


\begin{tabular}{lllll}
\hline$\backslash$ jciprod01\productn $\backslash L \backslash L C A \backslash 18-2 \backslash$ lca204.txt & unknown & Seq: 42 & 6 -AUG-12 & 11:45 \\
\hline
\end{tabular}

done with the minimum of physical and mental suffering appropriate to the circumstances.

The method chosen, except in an emergency, shall either:

a. cause immediate loss of consciousness and death; or

b. begin with the induction of deep general anesthesia to be followed by a step which will ultimately and certainly cause death.

The person responsible for the killing shall make sure that the animal is dead before the carcass is disposed of.

2. The following methods of killing shall be prohibited:

a. drowning and other methods of suffocation if they do not produce the effects required in Paragraph 1;

b. the use of any poisonous substance or drug, the dose and application of which cannot be controlled so as to give the effect mentioned in Paragraph 1 ; and

c. electrocution unless preceded by immediate induction of loss or consciousness.

Other methods and techniques which the Contracting Parties consider inappropriate may be listed in an Annex to this Protocol.

\section{ARTICLE 11: Reduction of Stray Animals}

When a Contracting Party considers that the numbers of stray animals present it with a problem, it shall take the appropriate legislative and/or administrative measures necessary to reduce their numbers in a way which does not cause avoidable pain, suffering, or distress.

a. Such measures shall include the requirements that:

i. if such animals are to be captured, this is done with the minimum of physical and mental suffering to the animal; and

ii. whether captured animals are kept or killed, this is done in accordance with the principles established in this Protocol.

b. Parties undertake to consider:

i. providing for dogs and cats to be permanently identified by some appropriate means which causes little or no enduring pain, suffering, or distress, such as tattooing as well as recording the numbers in a register together with the names and addresses of their owners;

ii. reducing the unplanned breeding of dogs and cats by promoting the neutering of these animals;

iii. encouraging the finder of a stray dog or cat to report it to the competent authority; and

iv. birth control methods for controlling the number of stray animals.

\section{ARTICLE 12: Information and Education Programmes}

The Contracting Parties undertake to encourage the development of information and education programmes so as to promote awareness and knowledge amongst organizations and individuals concerned with the keeping, breeding, training, trading, and boarding of companion animals of the provisions and the principles in this Protocol. In these programmes, attention shall be drawn in particular to the following subjects:

a. the need for training of companion animals for any commercial or competitive purpose to be carried out by persons with adequate knowledge and ability;

b. the need to discourage: 
i. gifts of companion animals to persons under the legal age, without the express consent of their parents or other persons exercising parental responsibilities;

ii. gifts of companion animals as prizes, awards, or bonuses;

iii. unplanned breeding of companion animals;

c. the possible negative consequences for the health and wellbeing of wild animals if they were to be acquired or introduced as companion animals; and

d. the risks of irresponsible acquisition of companion animals leading to an increase in the number of unwanted and abandoned animals.

Other issues and concerns that need to be addressed by Contracting Parties may be set out in an Annex to this Protocol.

\section{ARTICLE 13: Domestic Implementation}

1. Each Contracting Party shall adopt such domestic measures as are necessary to implement the provisions of this Protocol. Each Contracting Party shall designate an appropriate authority to carry out the responsibilities of this Protocol. A Party may adopt stricter, more protective, domestic legislation.

2. Each Contracting Party should provide a process for the confiscation and forfeiture of animals being held in violation of the Protocol and being treated in a manner in violation of this Protocol. The disposition of a confiscated animal will always be in a manner suitable to the needs and interest of the companion animal.

\section{ARTICLE 14: Annexes}

Annexes to this Protocol shall be created and changed in accordance with Article 21 of the Convention for the Protection of Animals.

\section{ARTICLE 15: Enforcement}

1. Each Contracting Party shall prohibit the keeping, breeding, training, or using of companion animals under conditions or in such a manner that violate the provisions of this Protocol or any of its Annexes. Legal responsibility shall rest upon both the owner and possessor of a companion animal.

2. Each Contracting Party may prohibit companion animal trade with any State which refuses to comply with the provisions of this Protocol and its Annexes.

\section{ARTICLE 16: Signature}

1. The present Protocol shall be available for signature by all States and the European Economic Community.

2. The present Protocol shall be open for signature at until and thereafter until

ARTICLE 17: Ratification, Acceptance, Approval

The present Protocol shall be subject to ratification, acceptance, or approval. Instruments of ratification, acceptance, or approval shall be deposited with the Government of which shall be the Depositary Government. 


\begin{tabular}{lllll}
\hline$\backslash$ jciprod01 $\backslash$ productn $\backslash L \backslash L C A \backslash 18-2 \backslash$ lca204.txt & unknown & Seq: 44 & 6-AUG-12 & $11: 45$ \\
\hline
\end{tabular}

ARTICLE 18: Accession

The present Protocol shall be open indefinitely for accession. Instruments of accession shall be deposited with the Depositary Government.

\section{ARTICLE 19: Entry into Force}

1. The present Protocol shall enter into force ninety days after the date of deposit of the tenth instrument of ratification, acceptance, approval, or accession with the Depositary Government.

2. For each State which ratifies, accepts, or approves the present Protocol or accedes thereto after the deposit of the tenth instrument of ratification, acceptance, approval, or accession, the present Protocol shall enter into force ninety days after the deposit by such State of its instrument of ratification, acceptance, approval, or accession.

\section{ARTICLE 20: Denunciation}

Any Contracting Party may denounce the present Protocol by written notification to the Depositary Government at any time. The denunciation shall take effect twelve months after the Depositary Government has received the notification.

\section{ARTICLE 21: Depositary}

1. The original of the present Protocol, in the English, French, and Spanish languages, each version being equally authentic, shall be deposited with the Depositary Government which shall transmit certified copies thereof to all States that have signed it or deposited instruments of accession to it.

2. The Depositary Government shall inform all signatory and acceding States and the Secretariat of signatures, deposit of instruments of ratification, acceptance, approval, or accession, entry into force of the present Protocol, amendments thereto, entry, and withdrawal of reservations and notifications of denunciation.

3. As soon as the present Protocol enters into force, a certified copy thereof shall be transmitted by the Depositary Government to the Secretariat of the United Nations for registration and publication in accordance with Article 102 of the Charter of the United Nations.

In witness whereof the undersigned Plenipotentiaries, being duly authorized to that effect, have signed the present Protocol. 